\title{
DIGESTIBILIDADE E VALOR BIOLÓGICO DA PROTEINA DA LEVEDURA SECA (Sacharomyces spp.) E DO FARELO DE SOJA PARA COELHOS
}

\author{
ANA REGINA TECHIATTI FAZANO \\ Zootecnista
}

Orientador: Dr. CYRO FÚLVIO ZINSLY

Dissertação apresentada à Escola Superior de Agricultura "Luiz de Queiroz", da Universidade de São Paulo, para obtenção do título de Mestre em Agronomia. Área de Concentração: Nutrição Animal $\theta$ Pastagens.

$P|R A C| C A B A$

Estado de São Paulo - Brasil Junho - 1986 
.11.

Ao mei pai

Nelson ("in memoria")

Dedico

A minha mae Maria

e irmãos Francisco e Carlos

Ofereço. 


\section{AGRADECIMENTOS}

Ao Prof. Dr. Cyro fúlvio Zinsly cuja amizade, dedicação e orientação tornou-se possível a realização deste trabalho.

Ao Prof. Dr. Wilson Roberto Soares Mattos pelo incentivo, colaboração e sugestões deste trabalho

Ao Prof. Dr. Roberto Dias de Moraes e Silva pelo apoio e sugestões no Summary.

- Ao Prof. Dr. Urineu Umberto Packer pela colaboração na análi se estatística.

- A Financiadora de Estudos e Projetos (FINEP), à Coordenação de Aperfeiçoamentos de Pessoal de Nível Superior (CAPES), ao Conselho Nacional de Desenvolvimento Científico e Tecnológico (CNPq) e a Fundação "Judith Buzaid" de Jaboticabal pela ajuda financeira concedida durante o curso de Pós-Graduação.

- A Faculdade de Ciências Agrârias e Veterinárias - UnEsp de Jaboticabal na pessoa do Prof. Dr. Ronaldo Dessimoni Carre gal pelo empréstimo das gaiolas metabólicas. 
A Granja São Roque - Piracicaba pelo fornecimento dos anzmais.

- Á Usina Bom Retiro-Capivari pelo fornecimento da levedura seca.

- Á Fábrica de Papel Piracicaba - Pirapel pelo fornecimento da polpa de celulose.

- A DURATEX - Rações Anhanguera S/A - Campinas pela análise dos aminoácidos.

- À Técnica de Laboratório Ana Maria Zani de Moura pelo auxílio nas anālises laboratoriais. 


\section{INDICE}

Pãg .

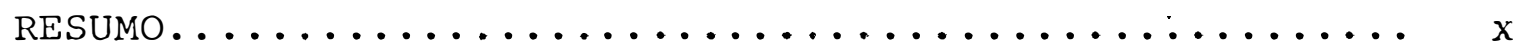

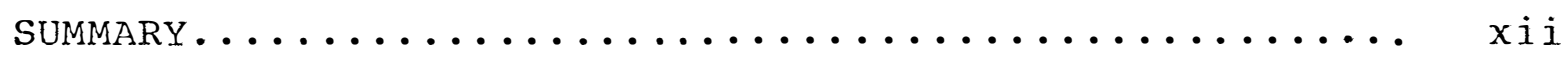

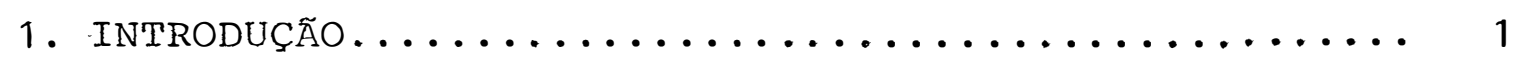

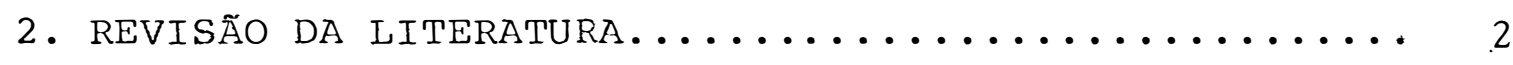

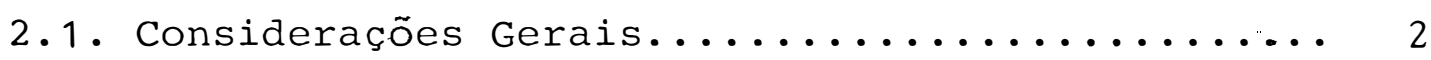

2.1.1. Composição đuímica..................6 6

2.1.2. Digestibilidade e valor biológico da pro 13

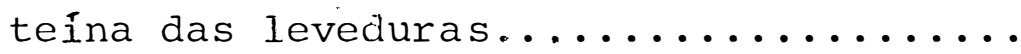

2.2. Metabolismo proteico em coelhos.............. 18

2.2.1. Aparelho digestivo e cecotrofagia...... 18

2.3. Uso da levedura para os coelhos............ 23

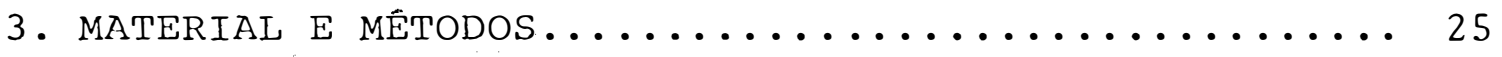

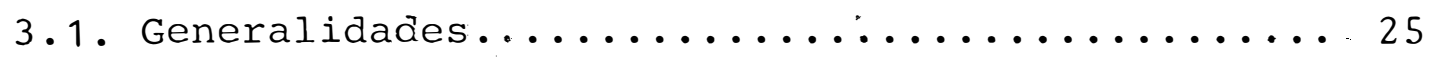

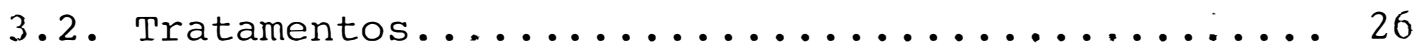

3.3. Rações experimentais................... 27

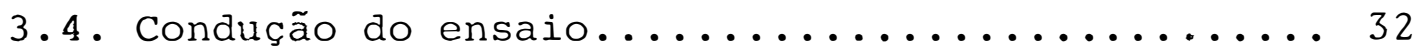

3.5. Coleta e preparo das amostras para análises quí

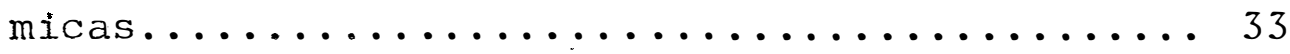

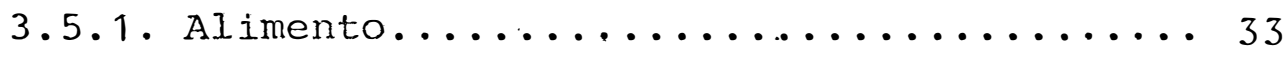

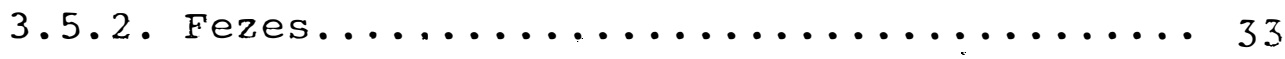

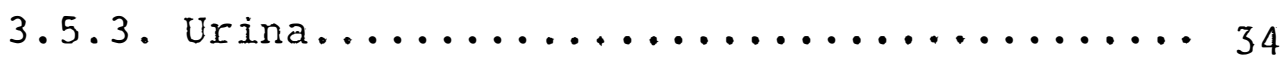


Pág.

3.6. Cálculo do Coeficiente de Digestibilidade e do

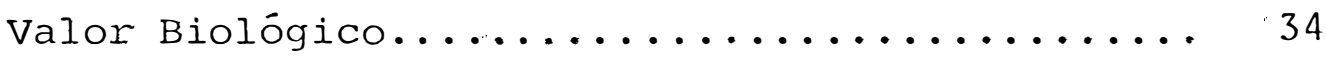
3.6.1. Coeficiente de digestibilidade aparente. $\quad 34$ 3.6.2. Valor Biológico Aparente............ 35

3.7. Delineamento experimental e Análise da variān-

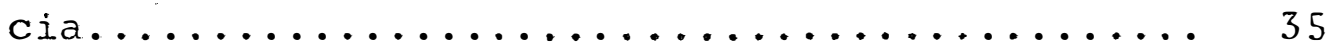

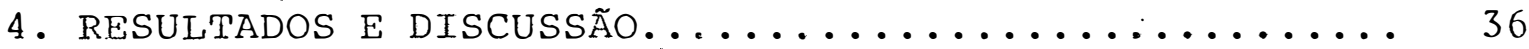

4.1. Consumo de Alimento.................. 36

4.2. Coeficiente de Digestibilidade Aparente...... 39.

4.3. Valor biológico aparente................ 42

5. CONCLUSOES............................. 48

6. IITERATURA CITADA............................... 50

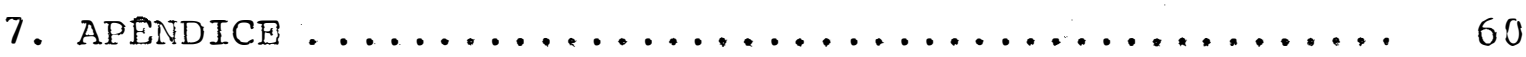


.vii.

\section{LISTAS DE TABELAS}

Pág.

1 Composiçã் química bromatológica das leveduras (Saccharomyces spp.) de álcool de cana-de-açú-

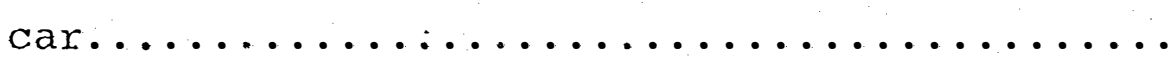

2 Composição em minerais das leveduras da espécie saccharomyces $\operatorname{spp} \ldots \ldots \ldots \ldots \ldots \ldots \ldots$

3 Composição em aminoácidos essenciais das leveduras de Saccharomuces snn. e do farelo de so-

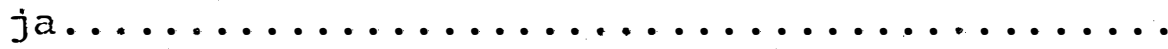

4 Coeficiente de digestibilidade aparente (C. $D_{a}$ )

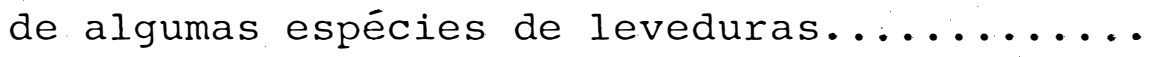

5 Valor biológico aparente $\left(\mathrm{V} \cdot \mathrm{B}_{\mathrm{a}}\right)$ de algumas espécies de leveduras suplementadas ou não com

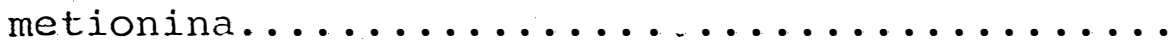

6 Capacidade relativa das diferentes partes do aparelho ḋigestivo do coelho, comparada com algumas espécies de animais domésticos.........

7 Composição química bromatológica dos ingredien

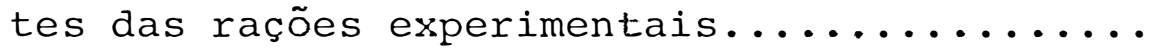


8 Composição em aminoácidos do farelo de soja e

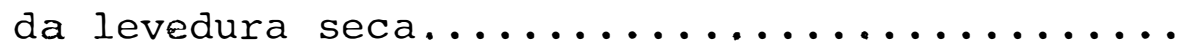

9 Composição média percentual das rações experi-

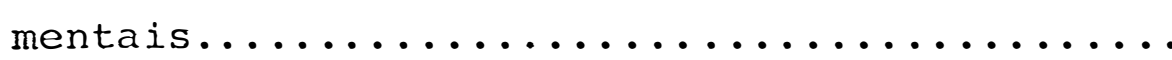

10 Composição quìmica bromatológica das rações ex

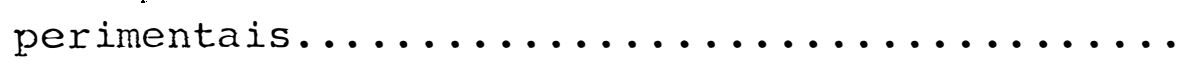

11 Delineamento experimental e análise da variân-

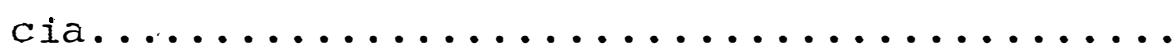

12 Médias para o consumo de matéria seca em gra-

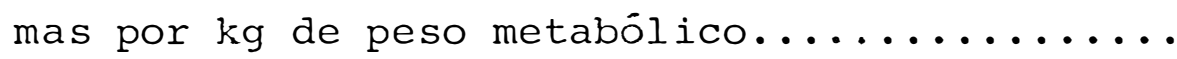

13 Análise da variância para o consumo de matéria seca por $\mathrm{kg}$ de peso metabólico............

14 Análise da variância para a variável fonte den

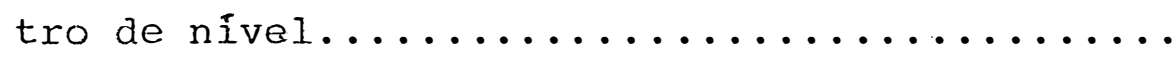

15 Análise da variância para a variável nível den

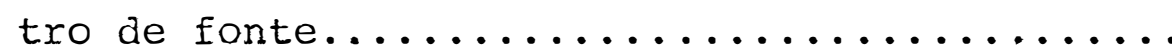


16 Médias dó coeficiente de digestibilidade apa-

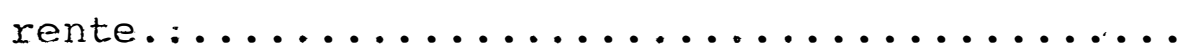

17 Análise da variāncia para o coeficiente de di-

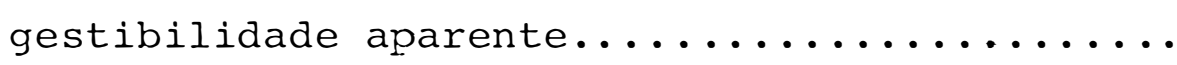

18 Médias do valor biológico aparente..........

19 Análise da variância para o valor biológico a-

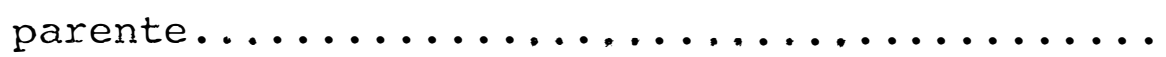

20 Médias do nitrogênio retido em relação aó inge

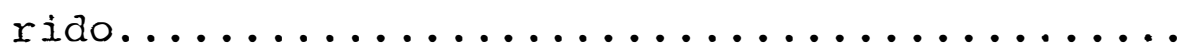

21 Análise da variância para o nitrogênio retido

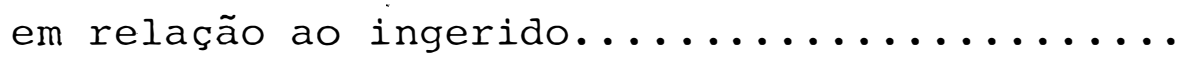

22 Médias do nitrogênio retido em relação ao dige

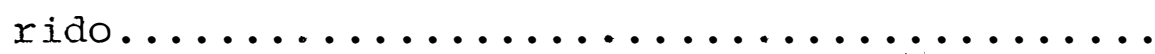

23 Análise da variância para o nitrogênio retido

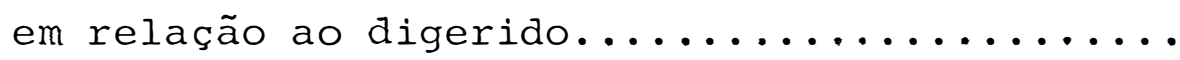




\title{
DIGESTIBILIDADE E VALOR BIOLÓGICO DA PROTEINA DA LEVEDURA SECA (Saccharomycesspp.) E DO FARELO DE SOJA PARA COELHOS
}

\author{
Autor: Ana Regina Techiatti Fazano \\ Orientador: Prof. Dr. Cyro Fúlvio Zinsly
}

\section{RESUMO}

O experimento teve a finalidade de determinar a qualidade da proteína da levedura seca (Saccharomyces spp) de destilarias de álcool de cana-de-açúcar para coelhos .em crescimento, através da digestibilidade e do valor biológico, comparativamente ao farelo de soja.

0 ensaio teve a duração de 28 dias, sendo 18 dias para a fase preliminar e 10 dias para a fase de coleta. Utilizou-se 20 láparos recém-desmamados com pe so médio inicial de $930 \pi$ e idade de 40 dias, de ambos os sexos, das raças Califórnia e Nova Zelândia Branco. Os animais fo

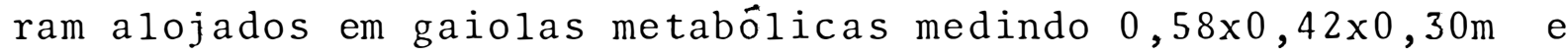
equipadas com comedouros e bebedouros automáticos.

Foram testados 4 tratamentos, através de um esquema fatorial envolvendo 2 fontes de proteína (levedura seca e farelo de soja) e dois níveis de proteína ( 8 e $12 \%$ ). Para cada tratamento foram utilizados 5 repetições de 1 animal. 
As médias dos coeficientes de digestibilidade aparente da proteína do farelo de soja: 93,37 e 91,44\%, respec tivamente para as rações contendo 8 e $12 \%$ de proteína bruta fo ram maiores $(P<0,01)$ aos observados para a levedura seca: 85,85 e $87,72 \%$, respectivamente para os mesmos níveis protéicos.

As diferenças quanto a valor biológico da proteína do farelo de soja: 51,96 e 56,53 e da levedura seca: 55,37 e 57,17 não foram estatísticamente diferentes nos dois níveis de proteína estudados.

Sugeriu-se que parte do nitrogênio não protéico da levedura foi utilizado pelos microorganismos do ceco na síntese protéica. 
.xii.

\section{DIGESTIBILITY AND BIOLOGICAL VALUE OF THE YEAST PROTEIN (Saccharomyces spp.) AND THE SOYBEAN MEAL FOR RABBITS}

Author: Ana Regina Techiatti Fazano Adviser: Prof. Dr. Cyro Fülvio Zinsly

\section{SUFMARY}

An experiment was carried out with growing rabbits in order to determine protein quality of dried yeast (Saccharomyces spp.) from sugar cane alcohol distillery. The protein quality was determined through digestibility and biological value compared to soybean meal.

The first 18 days of the experimental period (28 days) were utilized as a preliminary phase and the last 10 days for the sample collections.

Twenty California and White New Zealand weaned rabbits of both sexes were utilized as experimental animals with initial mean body weight of $930 \mathrm{~g}$ at 40 days of age.

The animals were housed in metabolic cages measuring $0.58 \times 0.42 \times 0.30 \mathrm{~m}$ with automatic feeders and waterers. The experimental design consisted of 4 treatments according to a factorial scheme envolving 2 protein sources 
(dried yeast and soybean meal) and 2 crude protein levels (C.P.) ( 8 and $12 \%)$.

Each treatment was alloted at random to 5 replicates (one animal per replicate).

The mean apparent digestibility coeficients of soybean meal were $93.37 \%$ and $91.44 \%$ for rations containing 8 and $12 \%$ C.P., respectively. These means were higher than those observed for dried yeast wich were $85.85 \%$ and $87.72 \%$, respectively for the same C.P. levels.

The differences between protein biological values in 8 and $12 \%$ C.P. Ievels for soybean meal $(51.96 \%$ and $56.53 \%$ ), and for dried yeast ( $55.37 \%$ and $57.17 \%$ ), respectively, were not satistically differents.

Based on the results, of the it can be suggested that part of non protein nitrogen of dried yeast was utilized by cecum microorganisms in protein synthesis. 


\section{INTRODUÇÃO}

Nos ûltimos tempos, a pesquisa no campo da nu trịção e da alimentação animal, tem sido direcionada no sentido de se substituir as fontes convencionais de nutrientes por fontes alternativas. Apesar deste procedimento visar prin palmente a redução nos gastos com alimentação, outras vantagens poderiam ser aventadas, tais como, meror competição ao homem em relação aos alimentos de uso comum e eliminação ou redução de subprodutos poluentes.

As fontes alternativas atualmente pesquisadas são das mais variadas origens, e dentre elas, a maior atenção tem sido dada aos microorganismos, os quais segundo KIHLBERG (1972), apresentam uma série de vantagens quando com parados às fontes convencionais de proteínas. Entre outros mo tivos, apresentam a vantagem de terem multiplicação râpida, 
produção independente das condições climáticas, utilizarem pequenas áreas,capacidade de se desenvolverem em diferentes tipos de substratos e ao final do processo, produzirem alimento com alto valor nutritivo.

Existem vários grupos de microorganismos que sao considerados como fontes de proteínas unicelulares, dentre os quais destacam-se as 1eveduras (DABBAH, 1970; KIHLBERG , 1972; YOUSRI, 1982), que tem sido consideradas as mais promissoras, fato que para o Brasil assume grande importância tendo-se em vista o potencial de produção da levedura seca (Saccharomyces spp) pelas destilarias de álcool.

As principais instituições de pesquisa brasileiras tem realizado inúmeros estudos com vistas à utilização da levedura seca na alimentação animal, sendo bastante variado o enfoque dado às referidas pesquisas.

Considerando-se que as leveduras são principalmente fontes de proteínas, no estudo do seu valor nutritivo é deveras interessante considerar as ponderações de ASPLUND e PFANDER (1972), para os quais, os experimentos de substitui ção de ingredientes, apesar de relativamente fäceis de serem conduzidos, nunca poderão ser considerados como conclusivos . Afirmam ainda que, a substituição parcial de uma fonte proté ca padrão por outra sob teste, talvez seja o delineamento me nos satisfatório, e concluem ser a avaliação biológica, envo 1 vendo balanço protêico entre outros, obrigatória no estudo da avaliação de subprodutos industriais como fonte protéica. 
Pelo exposto, o presente trabalho teve a finalidade precipua de determinar a qualidade da proteína da le vedura seca de destilaria de ảlcool de cana-de-açúcar para coe 1hos em crescimento, medida através da digestibilidade e do valor biológico. Para melhor aṕreciação dos resultados, os va lores obtidos foram comparados aos do farelo de soja, conside rado como padrão para proteína de origem vegetal. . 


\section{REVISÃO DE LITERATURA}

\subsection{CONSiderações gerais}

Embora existam vârias espécies de leveduras as quais por sua vez, sao cultivadas nos mais variados substratos, o interesse deste trabalho é abordar principalmente aspectos ligados a levedura da espécie saccharomyces spp produzida em destilarias de álcool de cana-de-açúcar, classifica das por DESMONTS (1968), como leveduras de recuperação.

As leveduras de recuperação constituem subpro dutos das destilarias produtoras de âlcool, e de forma resumi da são obtidas da seguinte maneira:

a) Após o término da fermentação, o vinho (mos to fermentado) é centrifugado, obtendo-se de um lado o vinho delevedurado e do outro, o leite de levedura.

b) Do total de leite de levedura obtido, 
maior parte é novamente enviada às dornas para fermentação de novas quantidades de mosto e o restante, em quantidades varia veis, é adicionada ảgua e novamente contrifugada denominandose esta operaçãa de lavagem. O número de lavagens é variâve1 dependendo do grau de pureza desejâvel no produto final.

c) Terminada a ültima lavagem, o leite de le vedura é encaminhado a secadores rotativos, onde além da des dratação, ocorre a morte parcial das leveduras. Saindo dosecador, tem se a levedura seca, utilizada na alimentação animal.

Estas leveduras pertencem ao gênero Saccharomyces, e as principais espécies são a Saccharomyces cerevisiae (STANIER et alii, 1969; LIMA et alii, 1975) e saccharomyces uvarum (LIMA. et alii, 1975), as quais tem sido constantemente selecionadas devido ao rápido crescimento e a boa produção de å1cool.

JACQUOT (1943), revelou que para as leveduras serem utilizadas sem incovenientes na alimentação dos animais devem ser mortas através do processo de desidratação, que provoca a ruptura da membrana celular, facilitando assim a di gestão. Células intactas apresentam menor digestibilidade e valor biológico como demonstrou COzzolino (1982), trabalhando com ratos.

Por outro lado, as leveduras vivas quando introduzidas no trato digestivo, apresentam a tendência de comportar-se como parasitas, isto é, apesar de seu elevado teor em algumas vitaminas, elas se utilizam de outras contidas no 
bolo alimentar, chegando a provocar verdadeiras avitaminoses (DESMONTS, 1968).

0 processo de desidratação além de prolongar o período de conservação das leveduras, facilita o transporte, armazenamento e incorporação às rações, além de evitar futu ros problemas digestivos decorrentes de fermentações anormais no aparelho digestivo.

\subsubsection{COMPOSIC,ĀO QUIMICA}

A composição química das leveduras pode variar em função do substrato na qual são cultivadas, método de fermentação, condições de secagem, concentração de minerais nos mostos de fermentação, 1avagem para eliminação das inpurezas, e ainda, idade das células (DESMONTS, 1968; KRIDER et alii, 1982). De todos estes fatores, o meio de cultura sobre a qual se desénvolvem é o que mais afeta a composição final das le veduras, principalmente em termos de proteínas e lipídeos (HSU, 1961).

$$
\text { Marques (1966), "apud" SALGADO (1976) e SAL- }
$$

GADO (1976), verificaram que leveduras cultivadas em meios contendo sais de amônia, continham significativamente maior teor de proteína quando comparados às cultivadas em meios con tendo nitrato.

Outro fator que também pode determinar altera ções significativas na composição química da levedura é o número de lavagens do leite. De acordo com SALGADO (1976), 1eite de levedura sem lavagem ou submetido a auatro lavagens, produziu leve- 
dura seca com teores de 33,62 e $42,09 \%$ de proteína bruta, res pectivamente, mas por outro lado, as lavagens provocaram perdas de 39,$40 ; 24,14$ e $84,52 \%$ de matéria seca, proteína e maté ria minerai, respectivamente, do material original.

A Tabela 1 apresenta a composição química bro matológica percentual de leveduras (Saccharomyces spp) de recuperação de destilarias de âlcool de cana-de-açû́car, na qual pode ser observada certa variação nos teores de alguns componentes. Provavelmente, as diferenças advém dos diferentes métodos de obtenção da levedura, os quais não são ainda padroni zados em nosso meio.

Indiscutivelmente, o aspecto de maior interesse na levedura seca é o seu teor de proteína, o qual pode ser variâvel em função dos fatores anteriormente apontados. A pesar de relativamente ricas neste nutriente, nem todo nitrogênio contido na levedura se encontra na forma de proteínas e aminoâcidos livres. Parte deste. conteúdo nitrogenadoen contra-se na forma não proteíca, principalmente âcidos nucléi cos, amônia, aminoácidos livres, glucosaminas, glutationa, ga lactosaminas, lecitina e outros compostos em menores concentrações (ROSE \& HARRISON, 1970).

Convém salientar que dentre os compostos nitrogenados de origem não protéica, os âcidos nucléicos são os que ocorrem em maiores quantidades, cerca de 8 a $12 \%$ do nitrogênio total (ROSE \& HARRISON, 1970; KIHLBERG, 1972 e 
Tabela 1 - Composição quínica bromatológica percentual de leveduras (Saccharomyces spp.) de recuperação de destilarias de álcool de ca na-de-açûcar.

\begin{tabular}{lcccccccc}
\hline & \multicolumn{7}{c}{ REFERENCIA } \\
\cline { 2 - 8 } & 1 & 2 & 3 & 4 & 5 & 6 & 7 & 8 \\
\hline Matéria seca & 90,70 & 93,03 & 91,92 & 93,90 & 89,42 & 92,89 & 87,34 & 89,10 \\
Proteína Bruta & 30,77 & 29,69 & 30,98 & 30,62 & 28,04 & 32,53 & $: 30,44$ & 39,50 \\
Fibra Bruta & 0,13 & 0,93 & 0,94 & 2,35 & 0,26 & 0,78 & 0,42 & 0,08 \\
Extrato Etéreo & 1,10 & 1,30 & 1,50 & 1,60 & 0,34 & 0,56 & 0,17 & 0,50 \\
Matéria Mineral & 9,81 & 13,24 & 4,27 & 9,82 & 4,86 & 5,43 & 3,55 & 7,78 \\
Extrativo não & & & & & & & 51,76 & 41,24 \\
Nitrogenado & 48,89 & 47,87 & 62,31 & 49,51 & 55,92 & 53,59 & 52,76 & \\
\hline
\end{tabular}

1) MIYADA E LAVORENTI (1979).

2) LIMA (1983).

3) MACHADO (1983).

4) FIALHO et alii (1983).

5) DURATEX (1985)...

6) DURATEX (1985).

7) FIALHO et alii (1985).

8) BATTISTI et alii (1985).

VANANUVAT, 1977). O alto teor de ácidos nucléicos encontrados nas leveduras é decorrente do räpido crescimento dos microrganismos e comumente é apontado como limitante à utilização. das leveduras na alimentação dos animais, quando fornecidas em grandes quantidades (HANSEN, 1981). 
No homem, o produto final do metabolismo das purinas é o ácido úrico, o qual, a partir de certos níveis no sangue, se precipita na forma de ureatos nos tecidos e articu lações, causando a gota e cálculos renais. Na maioria dos an mais, entretanto, o âcido úrico é metabolizado até alantoína,a qual é eliminada, via urina. (SLAGLE \& ZIMMERMAN, 1979 e HANSEN, 1981). Este fato sugere que níveis patológicos de áci do úrico no sangue não devemocorrer nos animais, mesmo quando recebem diariamente grandes quantidades de ácido nucléico como demons trado por HANSEN (1981), em suínos.

COzZOLINo (1982), estudando possíveis efeitos toxicológicos em sucessivas gerações de ratos utilizando a le vedura seca de saccharomyces cerevisiae como única fonte protêica, não observou anormalidades através dos exames histológicos. Resultados semelhantes foram obtidos por MATTOS et alii (1983), os quais substituiram totalmente a caseína das rações por levedura seca de Saccharomyces cerevisiae e não observa ram alterações no fígado, rins, baço e intestino dos ratos.

Por outro lado, SLAGLE \& ZIMMERMAN (1979), ava liaram o efeito da utilização do farelo de soja descorticado e de uma levedura contendo $61,8 \%$ de proteína bruta e $6 \%$ de ácidos nucléicos na matêria original na dieta de suínos recémdesmamados. Os resultados observados demonstraram que os ani- 
mais que receberam dietas à base de levedura apresentaram uma maior excreção urinária de nitrogênio total, de substânciasni trogenadas não especificas e de alantoína. Os níveis de âcido úrico no plasma foram inferiores a $0,5 \mathrm{mg} / 100 \mathrm{ml}$ para a soja e levedura, sendo considerados baixos e inócuos aos animais. Os carboidratos representam de 15 a $60 \%$ do pe so seco das leveduras, sendo representados em geral, por 33\% de dissacarídeos livres (trealose), 12\% por glicogênio, enquanto que o restante é encontrado na forma de polissacarídeos associados a proteínas e lipídeos. (PEPPLER, 1970 e ROSE \& HARRISON, 1970).

HANSEN (1981), recomendou que o teor de fibra bruta da. Ievedura seja adicionado ao conteúdo de extrativo não nitrogenado para efeito de cálculo do valor energético pelo fato do teor daquele nutriente ser extremamente baixo.

Com relação ao conteúdo energético FIALHO et alii (1983), trabalhando com a levedura seca de Saccharomyces spp de destilaria de âlcool de cana-de-açưcar utilizando suínos de diferentes idades, determinaram os valores de 3878 , 2908 e $2654 \mathrm{kcal} / \mathrm{kg}$ na matéria original respectivamente, para energia bruta, energia digestível e energia metabolizável.

As leveduras apresentam alto teor de matéria mineral (variando de 5 a $10 \%$ na matéria seca), sendo o potás sio e o fósforo seus maiores componentes. Os restantes apresentam-se na forma de fosfatos, sais de $\mathrm{Ca}, \mathrm{Mg}, \mathrm{Na}, \mathrm{Fe}$, e Sna forma de sulfitos (JACQUOT, 19.43; VANANUVAT, 19.77 e COZZOLINO, 
1982). Entretanto, as suplementações com minerais feitas no início da fermentação alcoólica e com a finalidade de proporcio nar melhores condições de fermentação, podem alterar a compos $\underline{i}$ ção final do produto. (HANSEN, 1981).

Embora a maioria das pesquisas mostrem excesso de fósforo em relação ao câlcio, MIYADA e LAVORENTI (1979); LIMA (1983) e FIALHO et alii (1983), trabalhando com a espécie Saccharomyces cerevisiae, obtiveram uma relação $\mathrm{Ca} / \mathrm{P}$ de 1,$78 ; 2,20$ e 1,97 as quais podem ser consideradas adequadas pa ra a alimentação dos animais.

A Tabela 2, mostra a composição em minerais de leveduras da espécie Saccharomyces spp de destilaria de âlcool de cana-de-açúcar.

Quanto às vitaminas, pode-se afirmar que as leveduras são muito ricas na maioria das vitaminas do complexo B (LIMA, 1966 e KIHLBERG, 1972) com exceção da B 12 ou cianocobalina (HANSEN, 1981 e YOUSRI, 1982)'e tem sido frequentemente utilizadas como suplemento vitamínico em dietas de monogástricos (VANANUVAT, 1977 e KRIDER et alii 1982), porém são desprovidas das vitaminas A e C (JACQUOT, 1943 e DESMONTS, 1968).

Além disso, as leveduras são ricas em ergosterol ou prô-vitamina $D$ que, mediante irradiação ultra-violeta converte-se em excelente fonte de vitamina D (KRIDER et alii, 1982), além de conterem fatores não identificados de crescimen to (LIMA, 1966). 


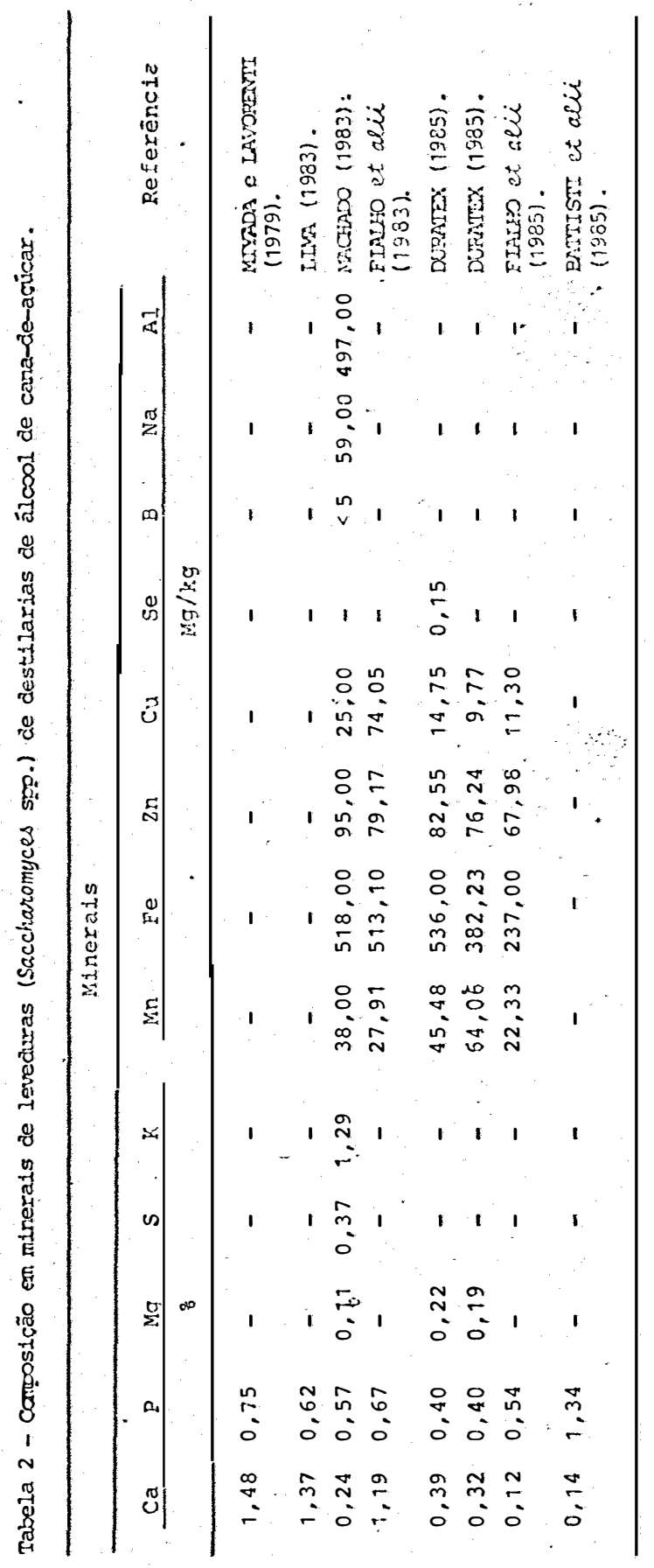




\subsection{2, DigestibiLidADE E VALOR BIOLÓGICO DA PROTEÍNA DAS LEVEDURAS}

Na bịliografia consultada, poucas informações foram obtidas com relação a digestibilidade da proteína da le vedura do gênero saccharomyces. COzzolino (1982), trabalhando com ratos, se utilizou de saccharomyces cerevisiae cultivada em melaço. de cana-de-açúcar e observou valor de $80,0 \%$ para o coeficiente de digestibilidade aparente da proteína. 0 autor considerou este valor bastante expressivo, visto os altos niveis de nitrogênio não protéico que as leveduras encerram.

FIALHO et alii (1983) e FIALHO et alii (1985), trabalhando com levedura de destilaria de ảlcool obtiveram va lores de 66,$44 ; 75,47$ e 85,$12 ; 93,05$ para os coeficientes de digestibilidade da proteína para suínos na fase de crescimento e acabamento, respectivamente. Por outro lado, BATTISTI et alii (1985) encontraram os valores de 67,80 e 83,70 para as mesmas categorias de suínos.

A Tabela 3 apresenta a composição em aminoâcí dos de leveduras (Saccharomyces spp) de destilarias de álcool de cana-de-açúcar e do farelo de soja, através da qual se observa que as leveduras apresentam elevados teores de lisina, razão pela qual sua utilização como suplemento protéico em dietas à base de cereais é recomendada (KIHLBERG, 1972). 


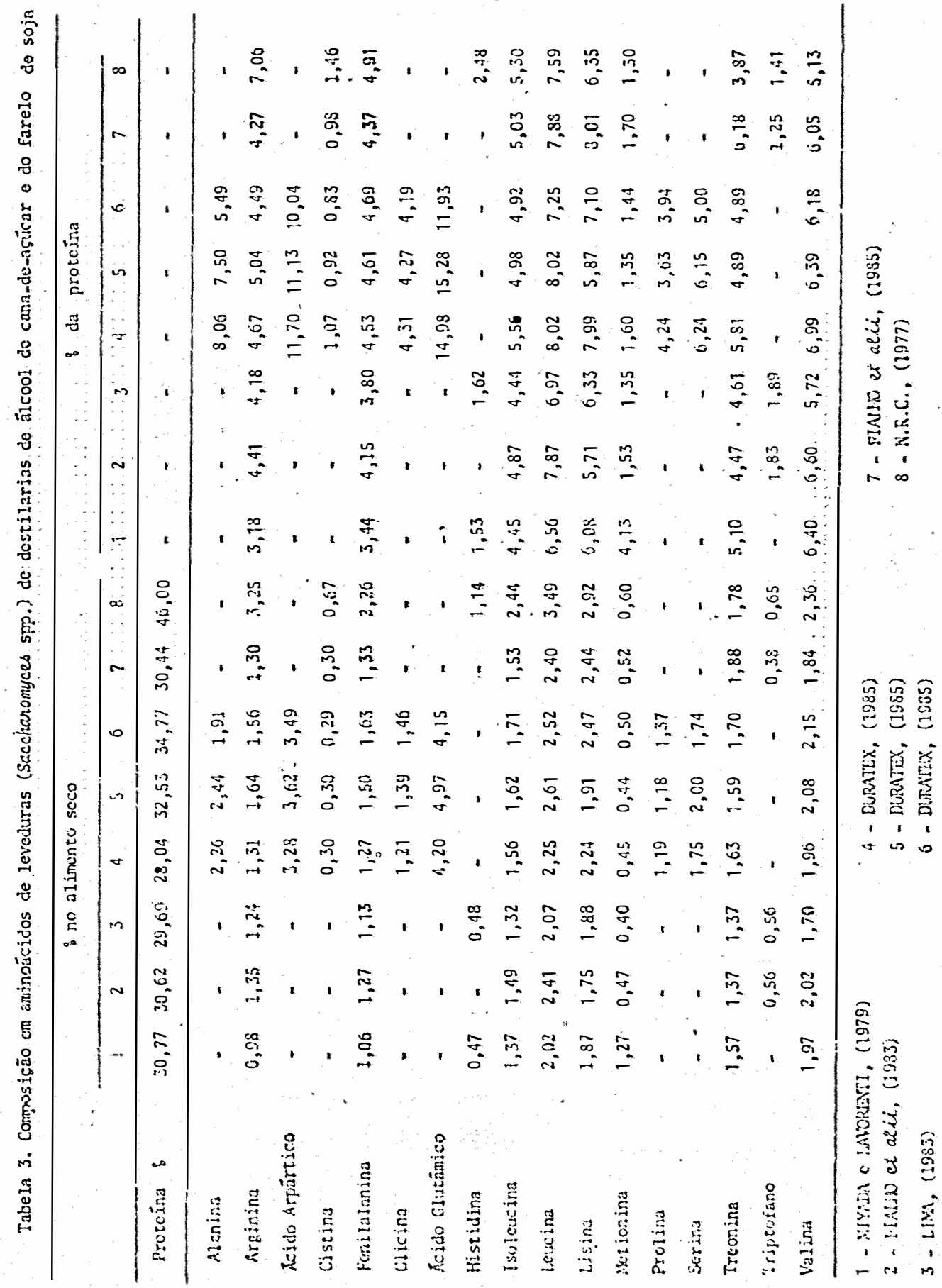


COzZOLINO (1982), estudando o valor nutritivo da levedura seca (Saccharomyces cerevisiae) cultivada em mela ço de cana-de-açücar, verificou que a proteína da levedura apresentou teor de lisina bastante superior ao encontrado na proteína do ovo, porëm, foi verificada deficiência moderada pa ra alguns aminoácidos essenciais, principalmente os sulfurados.

Por outro lado, NELSON et alii (1959), estuda ram 271 diferentes tipos de leveduras e observaram uma grande variação nos teores de lisina, metionina e triptofano entre as espécies e entre as linhagens de uma mesma espécie. Entretanto, observaram que a distribuição relativa dos três aminoá cidos foi geralmente a mesma, ou seja, lisina se apresentouem quantidades 5 a 6 vezes superiores ao de metionina e esta em quantidades 1,5 vezes maior que o triptofano. Os resultados de alguns ensaios biológicos fei to com ratos visando determinar a qualidade da proteína de le veduras estão apresentados na Tabela 4 , na qual se observa que a suplementação com metionina resultou em um aumento da qualí dade da proteína, fato que vem comprovar a deficiência desta nos aminoácidos sulfurados.

LIMA (1966), aponta a diferente composição em aminoácidos e a presença de níveis relativamente altos dos ácidos nucléicos como causa da variação nos resultados do valor biológico da proteína e consequentemente, no resultado do desempenho das espécies de animais domésticos. 
.16.

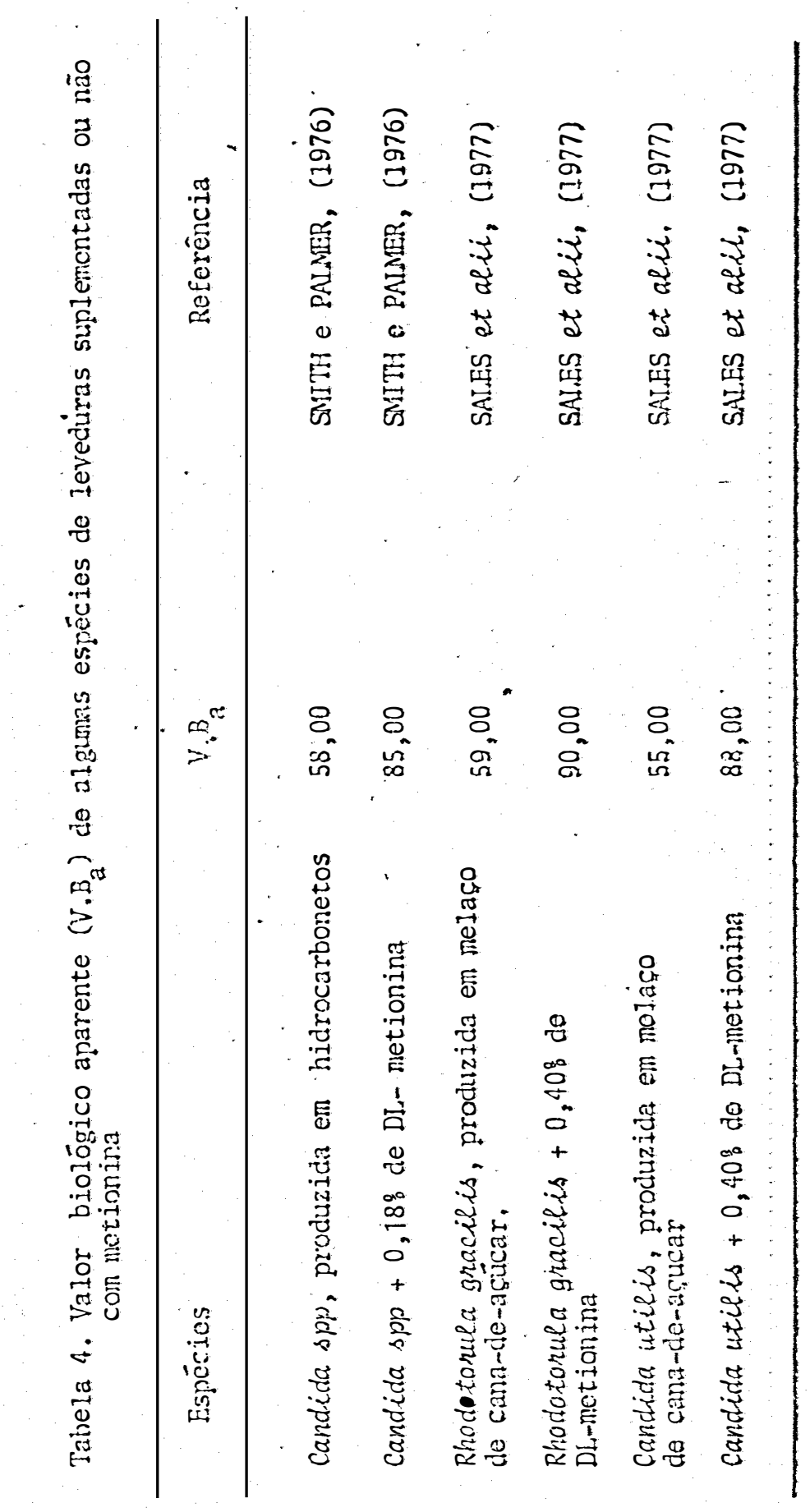


.17.

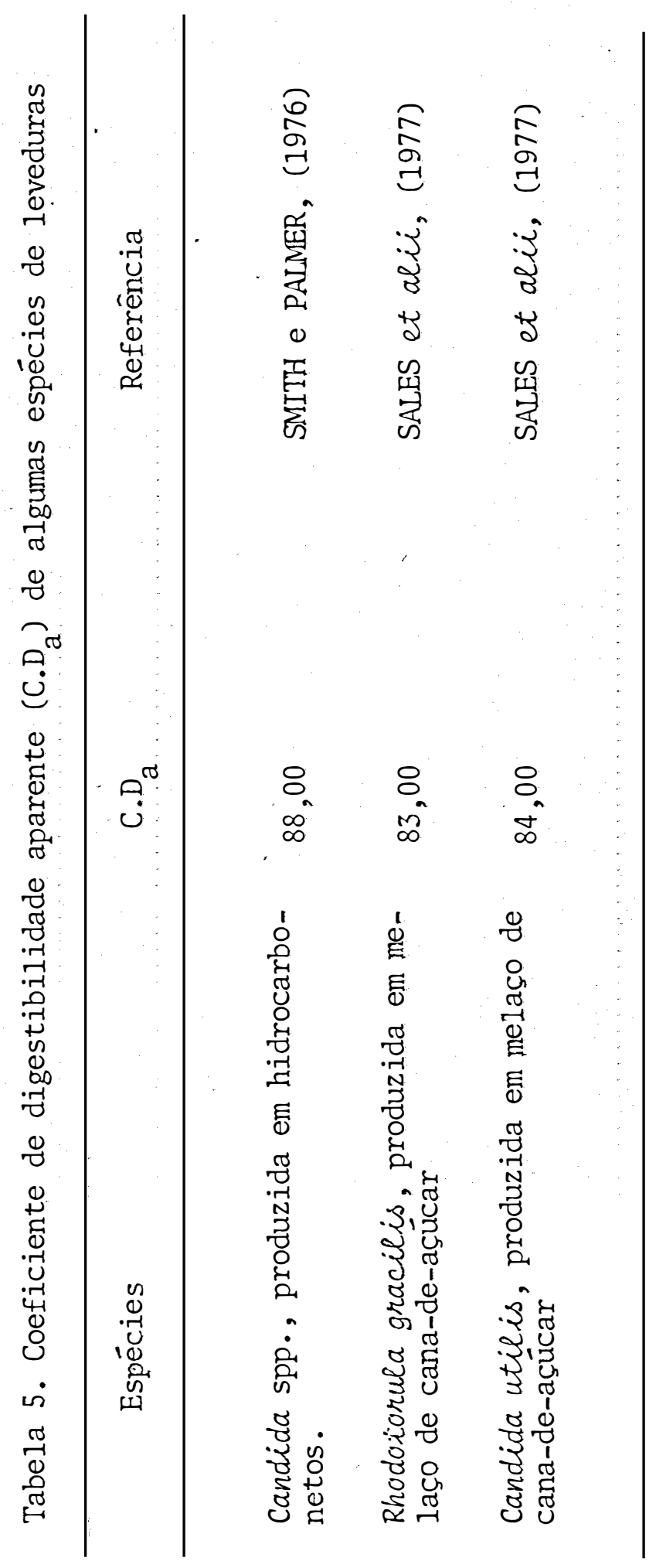


Apesar da composição quîmica sofrer variações com os diferentes tipos de leveduras e com o substrato, obser va-se de maneira geral, que as leveduras apresentam boa diges tibilidade de todos os seus nutrientes, em particular da fração nitrogenada (SLAGLE \& ZIMMERMANN, 1979 e HANSEN, 1981), co mo pode ser visto na Tabela 5 , na qual são apresentados os coeficientes de digestibilidade aparente da proteína de algumas espécies de leveduras, determinados com ratos.

\subsection{Metabolismo protéico em coelhos}

\subsubsection{Aparelho digestivo e cecotrofagia}

o coelho é classificado como um animal monogástrico herbívoro, apresentando aparelho digestivo proporcio nalmente bastante desenvolvido e capaz de digerir eficiente mente alimentos grosseiros e de baixa qualidade.

A. Tabela 6 mostra a capacidade relativa das diferentes partes do aparelho digestivo do coelho comparada com algumas espécies de animais domésticos, segundo SCHIOLAUT (1982).

o que se observa pela Tabela em questão, é o grande desenvolvimento do estomago e do ceco, orgãos responsâa veis respectivamente pela digestão química e microbiana dos alimentos.

A característica mais importante encontradano 
Tabela 6. Capacidade relativa das diferentes partes do aparelho digestivo do coelho $\left(\begin{array}{l}0 \\ 0\end{array}\right)$ comparada com algumas espécies de animais domésti cos.

\begin{tabular}{lcccc}
\hline & Bovinos & Equinos & Suínos & Coelhos \\
\cline { 4 - 6 } Estomago & 70 & 9 & 29 & 34 \\
Intestino Delgado & 19 & 30 & 33 & 11 \\
Ceco & 3 & 16 & 6 & 49 \\
Intestino Grosso & 8 & 45 & 32 & 6 \\
\hline
\end{tabular}

mecanismo de digestão dos coelhos é o fato dos mesmos habitual mente praticarem a Cecotrofagia a qual apresenta certas parti cularidades bastante interessantes.

TAYLOR (1940), verificou que as pelotas de fe zes encontrados no estomago do coelho eram tomadas diretamente do anus, deglutidas inteiras e que esta operação somente se realizava a noite. Posteriormente, THACKER \& BRANDT (1955) com a utilização de óxido crômico radiativo, provaram serem as fezes noturnas de origem cecal.

A comparação de que as fezes noturnas tem origem cecal, propiciou a melhor compreensão dos processos que tem lugar no ceco, como também permitiu melhor avaliação das vantagens advindas da ingestão destas fezes. Outra conseqüên cia foi a denominação de cecotrofe para as fezes noturnas e cecotrofagia para o processo de ingestão deste tipo particularde excreta. 
Sabe-se que consideráveis quantidades de ví taminas do complexo B são sintetizadas no ceco e aproveitadas através da cecotrofagia.

OLCESE e.t alii (1948), forneceram rações puri ficadas, quase isenta de ácido pantotênico, riboflavina, biot $\underline{i}$ na e ácido fólico e observaram na excreta dos coelhos quantida des muito superiores às ingeridas com a dieta. Posteriormente, OJCESE et alii (1949), em trabalho semelhante, verificaram que grandes quantidades de niacina eram também produzidas, através da sintese, no trato digestivo do coelho.

KULWICH et alii (1953), observaram que atravês da cecotrofagia, o coelho consegue obter $83 \%$ de niacina, $100 \%$ de riboflavina, $165 \%$ de ácido pantoténico e $42 \%$ de vitami na $B_{12}$ acima de suas necessidades.

Alêm da sintese de vitaminas, no ceco ocorre também produção de proteína microbiana, calculada por SPREAnBURY (1978), como sendo da ordem de 2,0 g por dia. Através da cecotrofagia, o coelho consegue aproveitar a proteína sintetizada no ceco, a qual por sua vez, concorre para aumentar a digestibilidade e o valor biológico da proteína do alimento, como foi demonstrado por HUANG et alii (1954); THACKER \& BRANDT (1955) e BATTAGLINI (1968) .

A redução na digestibilidade e na retenção de nitrogênio, como conseqüência da ausência da cecotrofagia é ex plicada por THACKER e BRANDT (1955), como resultado da alta ex creção de nitrogênio metabólico, o qual, quando ingerido atra- 
vês dos cecotrofes, passa a ser completamente aproveitado.

o aumento no valor biológico é conseqüência da sintese de aminoäcidos que ocorre no ceco (Proto, 1969 "apud" LANG, 1981). Aparentemente, a maioria dos aminoácidos são sintetizados, mas até o momento a síntese foi provada apenas para metionina e cistina (KULWICH et alii, 1954). Os autores forneceram ${ }^{35} \mathrm{~S}$ na forma de sulfato e, posteriormente detectaram a presença do elemento radiativo nos aminoácidos sulfurados.

Devido a esta síntese de aminoäcidos, o coelho adulto é capaz de sobreviver com dietas contendo proteína de baixa qualidade, desde que o alimento fornecido tenha todos os ingredientes necessärios para os microorganismos realizarem a sintese.

Por outro lado, sabe-se que coelhos jovens são extremamente dependentes dos aminoäcidos da dieta para crescimento normal e sempre respondem a suplementação com aminoầcidos essenciais como demonstraram McWARD et alii (1967); CHEEKE (1971); ADAMSON e FISHER (1973) e (1976); Davidson \& Spreadbury (1973)e Spreadbury (1974) "apud" LANG (1981), trabalhando com arginina, CHEEKE (1971) ADAMSON E FISHER (1973); COLIN (1975); SPREADBURY (1978) com metionina e lisina.

Apesar do conhecimento dos fatos descritos an teriormente, a exigência de coelhos em crescimento para os ami noácidos essenciais ainda não está estabelecida, em virtude da disparidade nas informações disponíveis. Segundo BALDISSERA (1982), a principal causa destas variações se deve ao desconhe 
cimento da exigência para certos nutrientes, bem como, os métodos utilizados.

Para determinação da exigência proteíca e de aminoâcidos comumente tem-se utilizado o método do balanço de nitrogênio e anâlise de carcaça, os quais possuem suas vantagens e desvantagens. Apesar das limitações, o método do balanço de nitrogênio tem sido o mais utilizado.

Para interpretar os dados obtidos pela têcnica do balanço de nitrogênio é necessârio considerar as excre ções urinârias e metaböiicas fecais, que servirão para estimar a digestibilidade verdadeira e a qualidade da proteína, expres sa pelo valor biolögico. Infelizmente, a determinação do nitro gênio endôgeno urinário e metabólico fecal, é afetado pelas di. ficuldades nas coletas e incorreções dos métodos BALDISSERA (1982) .

Além destes aspectos, outros tem sido coriside rados com a finalidade de melhorar a precisão nos resultados do balanço de nitrogênio. SLADE e ROBINŚON (1970) e BALDISSERA (1982), obtiveram balanço positivo de nitrogênio em coelhos adultos com ingestão diäria respectivamente de 1,56 e $1,20 \mathrm{~g}$ de proteína digestível por quilo de peso vivo.

BALDISSERA (1982), relata ainda que os animais mantiveram o peso corporal recebendo 3,80 ou $8,50 \mathrm{~g}$ de proteína digestível por dia e que dietas contendo $5,0 \%$ de proteína brutanão foram suficiente para manutenção do peso dos an mais. 


\subsection{Uso da leVEDURA para OS COELHOS}

Em virtude do potencial brasileiro de produção e do seu valor nutritivo, muitos estudos tem sido realizados com o intuito de se averiguar a possibilidade e os níveis de utilização da levedura seca de Saccharomyces spp de recupe ração das destilarias de álcool de cana-de-açûcar na alimenta ção dos animaís domésticos. Os resultados obtidos atê o momento são promissores e justificam o estudo deste subproduto com vista à alimentação dos coelhos.

Porêm, atê o momento são bastante escassas as informações sobre a utilização de microorganismos na alimentação destes roedores, principalmente, em se tratando de informa ções acerca do seu valor nutritivo em termos de digestibilidade e valor biológico da proteína e suas normas de utilização.

ATABEKYAN et alii (1977), forneceram micêlio de Aspergillus niger (subproduto da fabricação de ácido cítrị co) em vârias proporções para coelhos em crescimento e não obtiveram diferença significativa no ganho de peso e indice de conversão alimentar entre o lote testemunha e aos animais que haviam recebido micélio.

Por outro 1ado, CANTONI e D'AUBERT (1977), se utilizaram de um produto industrial (ZIMOYEAST), provenientes, de culturas de Saccharomyces cerevisiae e Kluvieromyces fragilus para estudar o efeito do fornecimento da levedura viva sobre 
as bactérias do intestino. Decorridos 7 e 15 dias do início do fornecimento, os coelhos estavam 6 e $10 \%$ respectivamente mais pesados que a testemunha e tinham maior quantidade de levedura no estomago e ceco, e apresentaram tendência a inibição de bactêrias Gran-negativas e redução do pH no estomago, ceco e fezes.

No Brasil, resultados preliminares citados por PROENÇ.A et alii (1982), indicaram a possibilidade de utilização da levedura seca de destilaria de álcool de cana-de-açúcar para os coelhos. Os autores testaram a possibilidade do uso da levedura recuperada no processo de produção de álcool como foil te protéica para 20 coelhos em crescimento (45 até 70 dias de idade). Foram utilizadas 4 rações fareladas contendo níveis de $0 ; 10$ e $15 \%$ de levedura. Não foram encontradas diferenças significativas para ganho de peso, consumo diārio de ração, conversão alimentar, rendimento de carcaça, como também não foi observado alteração na taxa de mortalidade dos animais em função dos tratamentos utilizados. 


\section{MATERIAL E MÉTODOS}

\subsection{Generalidades}

O ensaio foi conduzido no Laboratörio de Bromatologia do Departamento de Zootecnia da Escola Superior de Agricultura "Luiz de Queiroz" - ESALQ, Piracicaba.

Foram utilizadas láparos recém-desmamados com peso médio inicial de $930 \mathrm{~g}$ e idade de 40 dias, de ambos os sexos, das raças Califórnia e Nova Zelândia Branco e procedentes da Granja São Roque, em Piracicaba.

Os animais foram alojados em gaiolas metabóli cas medindo $0,58 \times 0,42 \times 0,30 \mathrm{~m}$, descritas por CARREGAL (1976), e equipadas com comedouros e bebedouros automáticos. 


\subsection{TRATAMENTOS}

Na bibliografia consultada não foram encontradas informações à ṛespeito do nível adequado de proteína pa ra ensaios do tipo utilizado no presente trabalho. Por esta ra zão, realizou-se um ensaio preliminar no qual foram utilizadas rações contendo 12 e $16 \%$ de proteína bruta, de acôrdo com as recomendações do N.R.C. (1977), o qual preconiza aqueles nịveis para coelhos em manutenção e crescimento, respectivamente.

A ração com $16 \%$ de proteína bruta e que cont nha $60 \%$ de levedura seca, se mostrou inadequada, pois os animais foram acometidos de severa diarréia, causando inclusive a morte de alguns.

Como a ŕação que continha levedura seca e $12 \%$ de proteína bruta se mostrou adequada, optou-se pela reduçãodo nível de proteína para $8,0 \%$. Assim, os tratamentos utilizados foram os seguintes:

\begin{tabular}{cl}
\hline Tratamentos & \multicolumn{1}{c}{ Caracterização } \\
\hline $\mathrm{S}_{8}$ & ração contendo farelo de soja e $8,0 \%$ de proteína bruta \\
$\mathrm{L}_{8}$ & ração contendo levedura seca e $8,0 \%$ de proteína bruta \\
$\mathrm{S}_{12}$ & ração contendo fare1o de soja e $12,0 \%$ de proteína bruta \\
$\mathrm{L}_{12}$ & ração contendo levedura seca e $12,0 \%$ de proteína bruta \\
\hline
\end{tabular}




\subsection{RAÇŌES EXPERIMENTAIS}

A formulação das rações experimentais foi baseada na recomendação de GAMAN e FISHER (1970), para rações purificadas e segundo as análises quîmicas bromatológicas dos ingredientes, a qual $\vec{e}$ apresentada na Tabela 7 . A composiçãoem aminoácidos do farelo de soja e levedura seca, é mostrada na Tabela 8 .

A polpa de celulose foi fornecida pela PIRAPEL - Indústria de Papel Piracicaba S/A e apresentava alto teor de umidade, motivo pelo qual foi necessâria secagem em estufa à $60^{\circ} \mathrm{C}$ para posteriormente ser submetida a moagem em moinho de martelo com perreira de $2 \mathrm{~mm}$.

A levedura foi obtjda junto a Usina Bom Retiro, município de Capivari - SP.

Para a peletização, utilizou-se equipamento marca SILVER modêlo CZ-350, sem vapor, tendo os pelets, $4 \mathrm{~mm}$ de diâmetro e $6 \mathrm{~mm}$ de comprimento.

A Tabela 9 apresenta a composição média percentual das rações experimentais.

As anālises químicas bromatológicas realizadas com as amostras das rações experimentais coletadas durante o transcorrer do período experimental, revelaram a composição mé dia que estä apresentada na Tabela 10. 
Tabela 7. Cominosisio química brọnitológica percentual dos ingradientes das rasōes experinentais *

\begin{tabular}{|c|c|c|c|c|c|c|}
\hline & \multicolumn{6}{|c|}{ Ingradientes } \\
\hline & $\begin{array}{l}\text { Farelo do } \\
\text { soja }\end{array}$ & $\cdot$ & $\begin{array}{l}\text { Lovedura } \\
\text { scca. }\end{array}$ & $\begin{array}{l}\text { Polpa de } \\
\text { celulose }\end{array}$ & $\begin{array}{l}\text { Aniulo de } \\
\text { milloo }\end{array}$ & Açúcax \\
\hline $\begin{array}{l}\text { Materia } \\
\text { Seca }\end{array}$ & 86,65 & . & 96,65 & 95,11 & 89,19 & 99,56 \\
\hline $\begin{array}{l}\text { Proteína } \\
\text { bruta }\end{array}$ & 48,39 & & 26,75 & 0,00 & 0,25 & - \\
\hline $\begin{array}{l}\text { Fibra } \\
\text { bruta }\end{array}$ & 5,49 & & 0,36 & 83,15 & 0,03 & - \\
\hline $\begin{array}{l}\text { Extrato } \\
\text { etéreo }\end{array}$ & 0,44 & & 0,24 & 0,38 & 0,03 & - \\
\hline$\cdot$ & & & & & & \\
\hline $\begin{array}{l}\text { Materia } \\
\text { mineral }\end{array}$ & 6,17 & & 11,29 & 0,34 & 0,05 & 0,02 \\
\hline $\begin{array}{l}\text { Extrativo não } \\
\text { nitrogenacio }\end{array}$ & 26,16 & & 58,01 & 11,24 & 88,83 & $99,8.4$ \\
\hline $\begin{array}{c}\text { Nitrogenio } \\
\text { total }\end{array}$ & 7,56 & & 4,28 & - & $\therefore$ & - \\
\hline $\begin{array}{l}\text { Nitrogênio } \\
\text { não protéico }\end{array}$ & 0,48 & & 0,71 & - & - & - \\
\hline $\begin{array}{l}\text { Nitrogênio } \\
\text { protêico }\end{array}$ & 7,14 . & & 3,60 & - & - & - \\
\hline Cálcio & 0,39 & & 1,43 & - & - & - \\
\hline Fósforo & 0,57 & & 0,39 & - & - & - \\
\hline
\end{tabular}

* Laboratório de Bromatclogia do Departamento de Zootecnia da Escola Sinerior de Agriculeura "Luiz de Queiroz" - Eiracicaba. 
Tabela 8. Composjão cm aninoácicos do Farelo de Soja e da levedura Seca *

\begin{tabular}{|c|c|c|c|c|}
\hline & \multicolumn{2}{|c|}{ "no alimento } & \multicolumn{2}{|c|}{ ¿ da proteína } \\
\hline . & $\begin{array}{l}\text { Farelo de } \\
\text { soja }\end{array}$ & $\begin{array}{l}\text { Levelura } \\
\text { scea }\end{array}$ & $\begin{array}{l}\text { Farelo de } \\
\text { soja }\end{array}$ & $\begin{array}{c}\text { Levedura } \\
\text { seca }\end{array}$ \\
\hline Proćcina : & 48,39 & 26,75 & - & - \\
\hline A]anisua & 2,215 & 1,634 & 4,577 & 6,103 \\
\hline Arginins & 3,364 & 1,065 & 6,952 & 3,980 \\
\hline fcido Aspártico & 5,762 & 2,803 & 11,908 & 10,480 \\
\hline Cistina & 0,722 & 0,282 & 1,491 & 1,056 \\
\hline Ienilalanina & 2,355 & 0,965 & $4,86 ?$ & 3,608 \\
\hline Glicina & 2,099 & 1,670 & 4,338 & 4,000 \\
\hline Aciclo Glutâmico & $10,04 \%$ & 3,644 & 20,762 & 13,624 \\
\hline Isoleucina & 2,016 & 1,135 & 4,166 & 4,244 \\
\hline Loucina & 4,009 & $1 ; 819$ & $8,2.85$ & 6,800 \\
\hline Jisina & $2, .930$ & 1,681 & 6,055 & 6,290 \\
\hline Metionina & 0,664 & 0,370 & 1,372 & 1,384 \\
\hline Prolina & 2,689 & 0,919 & 5,558 & 3,548 \\
\hline Serina & 2,842 & $1,4.30$ & 5,873 & 5,348 \\
\hline 'Trcomina & 2,010 & 1,384 & 4,153 & $5,1 \%$ \\
\hline Triptolano & 0,590 & 0,283 & 1,220 & 1,060 \\
\hline Valina & 2,188 & 1,383 & 4,522 & 5,172 \\
\hline
\end{tabular}

* JURATEX - Raçōcs Anhanguera S.A. 
Tabela 9. Composição mẻdia percentual das rações experimentais

\begin{tabular}{|c|c|c|c|c|}
\hline \multirow[b]{2}{*}{ Ingredientes } & \multicolumn{3}{|c|}{ Tratamentos } & \multirow[b]{2}{*}{$\mathrm{L}_{12}$} \\
\hline & $\mathrm{S}_{8}$ & $I_{8}$ & $S_{12}$ & \\
\hline $\begin{array}{l}\text { Farelo de } \\
\text { soja }\end{array}$ & 16,60 & - & 25,00 & - \\
\hline $\begin{array}{l}\text { Levedura } \\
\text { seca }\end{array}$ & - & 30,00 & - & 45,00 \\
\hline $\begin{array}{l}\text { Polpa de } \\
\text { celulose }\end{array}$ & 15,20 & 16,20 & 14,50 & 16,00 \\
\hline $\begin{array}{l}\text { Amido de } \\
\text { milho }\end{array}$ & 56,30 & 42,80 & 48,70 & 28,90 \\
\hline $\begin{array}{c}\text { Oleo de } \\
\text { soja }\end{array}$ & 4,00 & 4,00 & 4,00 & 4,00 \\
\hline Açücar & 5,00 & 5,00 & 5,00 & 5,00 \\
\hline Premix* & 0,60 & 0,60 & 0,60 & 0,60 \\
\hline Sal & 0,50 & 0,50 & 0,50 & 0,50 \\
\hline $\begin{array}{l}\text { Fosfato } \\
\text { bicálcico }\end{array}$ & 1,30 & 0,90 & 1,00 & - \\
\hline $\begin{array}{l}\text { Farinha de } \\
\text { ostra }\end{array}$ & 0,50 & 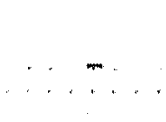 & 0,70 & - \\
\hline Total & 100,00 & $100 ; 00$ & 100,00 & 100,00 \\
\hline
\end{tabular}

* Premix mineral e vitamínico (Supre ilais produtos bioquímicos Ltda) suprindo as seguintes quantidades por $\mathrm{kg}$ de ração: $12 \mathrm{mg}$ de $\mathrm{Cu}$;

$80 \mathrm{mg}$ de Fe; $5 \mathrm{mg}$ de I; 60mg de $\mathrm{Mm}$; $1 \mathrm{mg}$ de Se; $50 \mathrm{mg}$ de $\mathrm{Zn} ; 7.500$ U.I. de vit.A; 1.000 U.I. de vit $D_{3} ; 10 \mathrm{mg}$ de vit $E ; 3 \mathrm{mg}$ de vit $K_{3} ; 2 \mathrm{mg}$ de vit $B_{1} ; 4 m g$ de vit $B_{2} ; 10$ mg de vit $B_{2} ; 8 m g$ de ácido Pantotênico; $20 \mathrm{mg}$ de Niacina; $250 \mathrm{mg}$ de Colina; $125 \mathrm{mg}$ de Etoxiquim e $125 \mathrm{mg}$ de Coccidiostático (Anpro1). 
Tabela 10. Composição quîmica bronatológica percentual das rações experinentais. *

\begin{tabular}{|c|c|c|c|c|}
\hline & \multicolumn{4}{|c|}{ Tratamentos } \\
\hline & $S_{8}$ & $L_{8}$ & $\mathrm{~S}_{12}$ & $\mathrm{~L}_{12}$ \\
\hline $\begin{array}{l}\text { Materia } \\
\text { seca }\end{array}$ & 94,10 & 93,76 & 94,30 & 94,74 \\
\hline $\begin{array}{l}\text { Proteína } \\
\text { bruta }\end{array}$ & 8,57 & 8,53 & 12,47 & 12,48 \\
\hline $\begin{array}{l}\text { Fibra } \\
\text { bruta }\end{array}$ & 13,41 & 12,50 & 13,49 & 12,63 \\
\hline $\begin{array}{l}\text { Extrato } \\
\text { etêreo }\end{array}$ & 4,25 & 4,18 & 4,99 & 4,50 \\
\hline $\begin{array}{l}\text { Materia } \\
\text { mineral }\end{array}$ & 3,27 & 4,76 & 3,57 & 5,58 \\
\hline $\begin{array}{l}\text { Extrativo } \\
\text { não nitrogenado }\end{array}$ & 63,59 & 63,18 & 60,77 & 60,54 \\
\hline
\end{tabular}

* Laboratório de Bromatologia do Departamento de Zootecnia da Escola Superior de Agricultura "Luiz de Queiroz" - Piracicaba. 


\subsection{CONDUÇÃAO DO ENSAIO}

O ensaio foi conduzido segundo o delineamento inteiramente ao acaso, constituído por 4 tratamentos com 5 repetições sendo 1 animal para cada repetição, no qual se utili zou a coleta total de fezes e urina.

Por ocasião do recebimento, os animais foram pesados, sexados, tatuados e distribuídos pelos tratamentos. Ca da tratamento recebeu igual número de animais quanto a raça, se xo e semelhança quanto ao peso.

A duração total do ensaio foi de 28 dias, sen do considerado um período preliminar de 18 dias e um principal ou de coleta de 10 dias. Durante o transcorrer do período experimental, os animais receberam ração e água à vontade, sendo o consumo de ração controlado diariamente e o fornecimento feito em apenas uma refeição, pela manhã.

As fezes eram coletadas diariamente por volta das 18:00 horas, embaladas em sacos plásticos e guardadas em congelador $\bar{a}-20^{\circ} \mathrm{C}$.

A coleta da urina era feita diariamente às 8:00 horas e guardadas em frascos contendo äcido clorídrico di luîdo em ăgua na proporção de $1: 1$, em quantidades diferentespá ra cada animal, mas suficiente para manter o $\mathrm{pH}$ abaixo de 3,0. Estas quantidades foram previamente determinadas no período pre liminar, mas diariamente o pH era medido e quando necessārio,

novas quantidades de ácido clorídrico eram adicionadas. Poste- $x$ 
riormente era guardada em frascos plásticos em geladeira $3^{\circ} \mathrm{C}$.

\title{
3.5. Coleta e PREPARO dÁs amostras PARA ANÁlises Químicas
}

\author{
3.5.1. ALIMENTO
}

Diariamente, antes do fornecimento aos animais, as rações experimentais eram devidamente homogeneizadase retirada amostras que em seguida eram guardadas em sacos plás ticos.

No final do período experimental, o material coletado foi moído em moinho tipo "Willey" com peneira de $1 \mathrm{~mm}$.

\section{$3,5.2$. FEZES}

Após o término do período de coleta, as fezes foram pesadas, e foram secas em estufa de ventilação for çada à $60^{\circ} \mathrm{C}$ durante 48 horas. Decorrido o tempo, o material foi retirado e deixado exposto ao ar para ocorrer o equilíbrio com o meio ambiente.

Estabilizada, as amostras foram novamente pesadas, obtendo-se assim a primeira matéria seca das fezes, e então moídas em moinho tipo "Willey" com peneira de $1 \mathrm{~mm}$. 


\subsubsection{URINA}

No final do ensaio, procedeu-se a medição do volume de urina coletada, desprezou-se metade do volume total e o restante foi mantido em geladeira para posterior análise.

\subsection{CÁlCULO DO COEFICIENTE DE DIGESTIBILIDADE E DO VALOR B ROLÓGICO}

A determinação dos constituintes químicos bro matológicos foram realizados seguindo os métodos descritos pela "Association of Official Agricultural Chemist" (A.O.A.C., $1980)$.

As fórmulas usadas para efetuar o cálculo do coeficiente de digestibilidade e do valor biológico estão des critas a seguir:

3.6.1. Coeficiente de digestibilidade aparente $\left(C, D_{A}\right)$

$$
\text { C. } \mathrm{D}_{\mathrm{a}}=1-\frac{\mathrm{N} . \mathrm{E} .}{\mathrm{N} . \mathrm{I} .} \times 100 \text { onde: }
$$

N.E. = nitrogênio excretado

N.I. = nitrogênio ingerido 
3.6.2. VALOR BIOLógico aparente $\left(V, B_{A}\right)$

V. $B_{a}=\frac{\text { N.I. }-(N \cdot F \cdot+\text { N.U. })}{\text { N.I. }- \text { N.F. }} \times 100$ onde:

N.F. = nitrogênio das fezes

N.U. = nitrogênio da urina

\subsection{Deílneamento experimental E anälise de VARiância}

Os dados foram analisados de acôrdo com o modêlo fatorial inteiramente ao acaso, envolvendo 2 fontes de proteína e 2 níveis protẹico, com 5 repetições de um animal.

O esquema de análise de variância ( PIMENTEL GOMES, 1985 ), está apresentada na Tabela 11 .

Tabela 11. Esquema de anâlise de variância

\begin{tabular}{lc}
\hline Fontes de variação & G.L. \\
\hline Rações & 3 \\
Fontes (F) & 1 \\
Níveis (N) & 1 \\
F X N & 1 \\
Resíduo & 16 \\
\hline Total & 19 \\
\hline
\end{tabular}




\section{RESULTADOS E DISCUSSÃO}

\subsection{CONSUMO DE ALIMENTO}

Com a finalidade de determinar o consumo volun tário, para posterior uniformização das quantidades de alinento a serem fornecidas, no período preliminar do ensaio, os animais receberam alimentação "ad libitum". Pelo fato do consumo se mostrar uniforme entre os tratamentos, decidiu-se continuar com o mesmo programa de arraçoamento.

Por ocasião da anâlise dos resultados, entretanto, foram observadas diferenças no consumo entre os tratamentos no período de coleta e por esta razão, procurou-se estudar com mais detalhes aquelas diferenças pois, de acordo com Reid \& Tyrrel (1964) "apud" MAYNARD et alii (1979) em coelhos o nivel de consumo afeta a digestibilidade dos nutrientes tanto de concentrados como de volumosos.

Na Tabela 12 são apresentados as médias de consumo de matéria seca por quilograma de peso metabólico e na Tabela 13 a respectiva análise da variância.

A análise da variância mostra que as diferen ças no consumo não foram significativas quanto à fonte e nível de proteína, mas forali significativas para a interação entre essas variáveis. Os desdobramentos dos graus de liberdade da interação, considerando fonte dentro de nível e nível dentro de fonte, são apresentados na Tabela 14 e Tabela 15, respectivamente. 
Tabela 12. Médias para o consumo de materia seca em gramas por $\mathrm{kg}$ de peso metabólico.

\begin{tabular}{cccc}
\hline \multirow{2}{*}{ Fontes } & \multicolumn{2}{c}{ Níveis } & \\
\cline { 2 - 3 } Farelo de soja & 8 & 12 & média/ fontes \\
\hline Levedura Seca & 401,34 & 400,20 & 375,50 \\
\hline Média / níveis & 376,07 & 383,01 & 383,58 \\
\hline
\end{tabular}

Tabela 1.3. Análise da variância para o consumo de matéria seca por $\mathrm{kg}$ de peso metabölico.

\begin{tabular}{lccc}
\hline $\begin{array}{l}\text { Causas de } \\
\text { variação }\end{array}$ & $\begin{array}{c}\text { Grau de } \\
\text { liberdade }\end{array}$ & $\begin{array}{c}\text { Quadrados } \\
\text { médios }\end{array}$ & Teste F \\
\hline Fontes (F) & 1 & 326,35 & $0,21^{\text {ns }}$ \\
Níveis (N) & 1 & 240,33 & $0,15^{\text {ns }}$ \\
F x N & 1 & 9012,13 & $5,78 \quad(\mathrm{P}<0,05)$ \\
Resíduo & 16 & 1559,97 & \\
\hline
\end{tabular}

Coeficiente de variação $($ C.V..$\%)=10,41$

N.S. = são significativo

$(\mathrm{P}<0,05)=$ significativo a nível de $5 \%$ de probabilidade. 
Tabela 14. Análise da variância para a variảvel fonte dentro de nível

\begin{tabular}{lccc}
$\begin{array}{c}\text { Causas de } \\
\text { variaçã̃o }\end{array}$ & $\begin{array}{c}\text { Grau de } \\
\text { liberdade }\end{array}$ & $\begin{array}{c}\text { Quadrados } \\
\text { médios }\end{array}$ & Teste F \\
\hline Fontes (F) & 1 & 326,35 & $0,21 \mathrm{~ns}$ \\
F/níve1 8 & 1 & $6.384,21$ & $4,09(\mathrm{P}<0,10)$ \\
F/níve1 12 & 1 & $2.954,27$ & $1,89 \mathrm{~ns}$ \\
Resíduo & 16 & $1.559,97$ & \\
\hline $\begin{array}{l}\text { NS }=\text { não significativo } \\
(\mathrm{P}<0,10)=\text { significativo a nível de } 10 \% \text { de probabilidade. }\end{array}$
\end{tabular}

Tabela 15. Análise da variäncia para a variável nível dentro de fonte

\begin{tabular}{lccc}
$\begin{array}{c}\text { Causas de } \\
\text { variação }\end{array}$ & $\begin{array}{c}\text { Grau de } \\
\text { liberdade }\end{array}$ & $\begin{array}{c}\text { Quadrados } \\
\text { médios }\end{array}$ & Teste F \\
\hline Níveis (N) & 1 & 240,33 & $0,15 \mathrm{~ns}$ \\
N/ soja & 1 & $6.097,94$ & $3,91 \quad(\mathrm{P}<0,10)$ \\
N/ levedura & 1 & $3.154,53$ & $2,02 \mathrm{~ns}$ \\
Resîduo & 16 & $1.559,97$ & \\
\hline
\end{tabular}

NS = não significativo

$(\mathrm{P}<0,10)=$ significativo à nível de $10 \%$ de probabilidade 
o desdobranento, considerando fonte dentro de nível, mostra que as diferenças observadas foram significati vas apenas para onivel dentrode 8,0\% de proteína, e o desclobramento para nível de fonte, mostra diferenças significativas para os dois níveis de proteína, sendo entretanto maior para o fare lo de soja.

Nas condições do ensaio, não foi possível detẹ minar a causa das variações, como tambêm fatos semelhantes não foram encontrados na literatura consultada.

\subsection{COEFIGIENTE DE DigestibILidAde APARENTE}

Os resultados obtidos para os coeficientes de digestibilidade aparente da proteína são apresentado nas Tabelas 16 e a respectiva anålise da variância na Tabela 17.

A análise da variância mostra que as diferenças entre os coeficientes de digestibilidade foram significativas a penas para as fontes de proteína e, portanto, que o farelo de soja foi superior à levedura.

Os resultados obtidos com relação a levedura po dem ser considerados altamente favoräveis se considerados os teores de nitrogênio não protéico (NNP) entre as duas fontes es tudadas. Assim, o farelo de soja e a levedura apresentaram teo res de 5,42 e $16,12 \%$ de $N N P$, respectivamente, fato que permite concluir ter havido aproveitamento do NNP da levedura para sín 
tese protêica e posterior recuperação da proteína sintetizada atravês da cecotrofagia, segundo os informes de HUANG et alii (1954); THACKER \& BRANDT (1955); BATTAGLINI (1968) e SPREADBURY (1.978) .

Por outro lado, o exame da Tabela 16. mostra que o aumento do teor de proteína da ração provocou redução na digestibilidade para o farelo de soja e inversamente, aumentou para levedura, como pode ser observado pelos indices relativos dos coeficientes de digestibilidade, mostrados na Tabela 18. Uma explicação plausível para o fato, seria que o aumento do teor de levedura na ração teria favorecido a sintese proteíca, mas as diferenças observadas quanto ao consumo de alimen to, torna perigosa a afirmação, pois o aumento ou redução no consumo póde ter contribuido para as alteraşões nos coeficientes de digestibilidade.

Os resultados obtidos no presente trabalho, re velam de maneira geral que os coelhos conseguem aproveitar com maior eficiência a fração nitrogenada da levedura seca de destilarias de álcool, quando comparado aos ratos e suínos. Assim COZzOLINo (1982), trabalhando com ratos e FIALHO et alii (1983) e BATTISTI et alii (1985) trabalhando com suínos, encontraram valores mais baixos para os coeficientes de digestibilidade da proteína de levedura. Valores mais altos foram encontrados por FIALHO et alii (1985) com suínos na fase de terminação e semelhantes para suínos na fase de crescimento.

Finalmente, os resultados obtidos no presente trabalho estão de acôrdo com outros autores, segundo os quais as leveduras apresentam alta digestibilidade de sua fração ni- 
Tabela 16. Médias do coeficiente de digestibilidade aparente da proteína.

\begin{tabular}{|c|c|c|c|}
\hline \multirow[b]{2}{*}{ Fontes } & \multicolumn{2}{|c|}{ Níveis $\left(\frac{0}{0}\right)$} & \multirow[b]{2}{*}{ mëdias/fontes } \\
\hline & 8 & 12 & \\
\hline farelo de soja & 93,37 & 91,44 & 92,40 \\
\hline levedura seca & 85,85 & $: 7,72$ & 86,78 \\
\hline Média/níveis & 89,61 & 89,58 & 89,59 \\
\hline
\end{tabular}

Tabela 17. Análise da variância para o coeficiente de digestibilidade aparente.

\begin{tabular}{lccc}
\hline $\begin{array}{c}\text { Causas de } \\
\text { variação }\end{array}$ & $\begin{array}{c}\text { Grau cle } \\
\text { liberdade }\end{array}$ & $\begin{array}{c}\text { Quadrados } \\
\text { médios }\end{array}$ & Teste F \\
\hline Fontes (F) & 1 & 157,7000 & $17,186(\mathrm{P}<0,01)$ \\
Nïveis (N) & 1 & 0,0100 & $0,0001 \mathrm{~ns}$ \\
F & 1 & 18,1232 & $1,975 \mathrm{~ns}$ \\
Residuo & 16 & 9,1758 & \\
\hline
\end{tabular}

Coeficiente de variação (C.V.\%) $=3,38$

NS = não significativo

$(\mathrm{P}<0,01)=$ significativo a nível de $1 \%$ de probabilidade.

Tabcla 18 - Indices relativos dos coeficientes de digestibilidade aparente para níveis de proteína.

\begin{tabular}{ccc}
\hline \multirow{2}{*}{ Fontes } & \multicolumn{2}{c}{ Niveis $\left(\begin{array}{l}0 \\
0\end{array}\right)$} \\
\cline { 2 - 3 } farelo de soja & 8 & 12 \\
levedura seca & 100 & 97,93 \\
\hline
\end{tabular}


trogenada, independente da espécie animal.

\subsection{VALOR BIOLÓGICO APARENTE}

Os resultados obtidos para o valor biológico a parente estão apresentados na Tabela 18 e a respectiva análise da variância na Tabela 19 .

Apesar da análise da variância mostrar que. as diferenças observadas não foram significativas para. as variâa veis consideradas, nota-se pequeno decréscimo no valor biológ co com o aumento do teor de proteína das rações e ainda, que o efeito foi menor na levedura, quando comparada ao farelo de so ja.

De maneira semelhante ao observado com os coeficientes de digestibilidade aparente, a síntese microbiana no ceco deve ter contribuído para os resultados observados quanto ao valor biológico da proteína da levedura, de acôrdo comos relatos de HUANG et alii (1954); , IHACKER \& BRANDT (1955);BATTA GLINI (1968); SPREADBURY (1978) e Proto "apud" LANG (1981), mas novamente, não pode ser desconsiderada a possibilidade do consumo de alimento ter influido também nos resultados.

No presente caso, entretanto, é possível se afirmar com relativa segurança que a síntese protéica microbiana contribuiu para melhor utilização da fração nitrogenada da levedura. Para tanto, basta observar os resultados de retenção de nitrogênio, apresentados nas Tabelas 20 e 22 e respec- 
tivas anâlises das variâncias nas Tabelas 21 e 23.

Apesar da análise da variância mostrar que as diferenças não foram significativas, observa-se que enquanto a retenção de nitrogênio em relação ao ingerido foi mais baixa para a levedura, a rétenção do nitrogênio em relação ao diger do aconteceu de maneira inversa.

Comparando-se a composição em aminoácidos do farelo de soja e da levedura, apresentada na Tabela 8 é possível verificar que a proteína da levedura apresenta alguns aminoácidos essenciais em níveis mais baixos aos observados para o farelo de soja e portanto, a maior retenção do nitrogênio di gerido talvez possa ser explicado pela melhora na qualidade da proteína da lẹvedura através da síntese protéica microbiana que ocorre no ceco.

Tabela 19. Médias do valor biológico aparente

\begin{tabular}{lccc}
\hline & \multicolumn{2}{c}{ Níveis } & \\
\cline { 2 - 3 } Fontes & 8 & 12 & Média/Fontes \\
\hline Farelo de Soja & 56,53 & 51,96 & 54,24 \\
Levedura Seca & 57,17 & 55,37 & 56,27 \\
\hline Média/níveis & 56,85 & 53,66 & 55,25
\end{tabular}




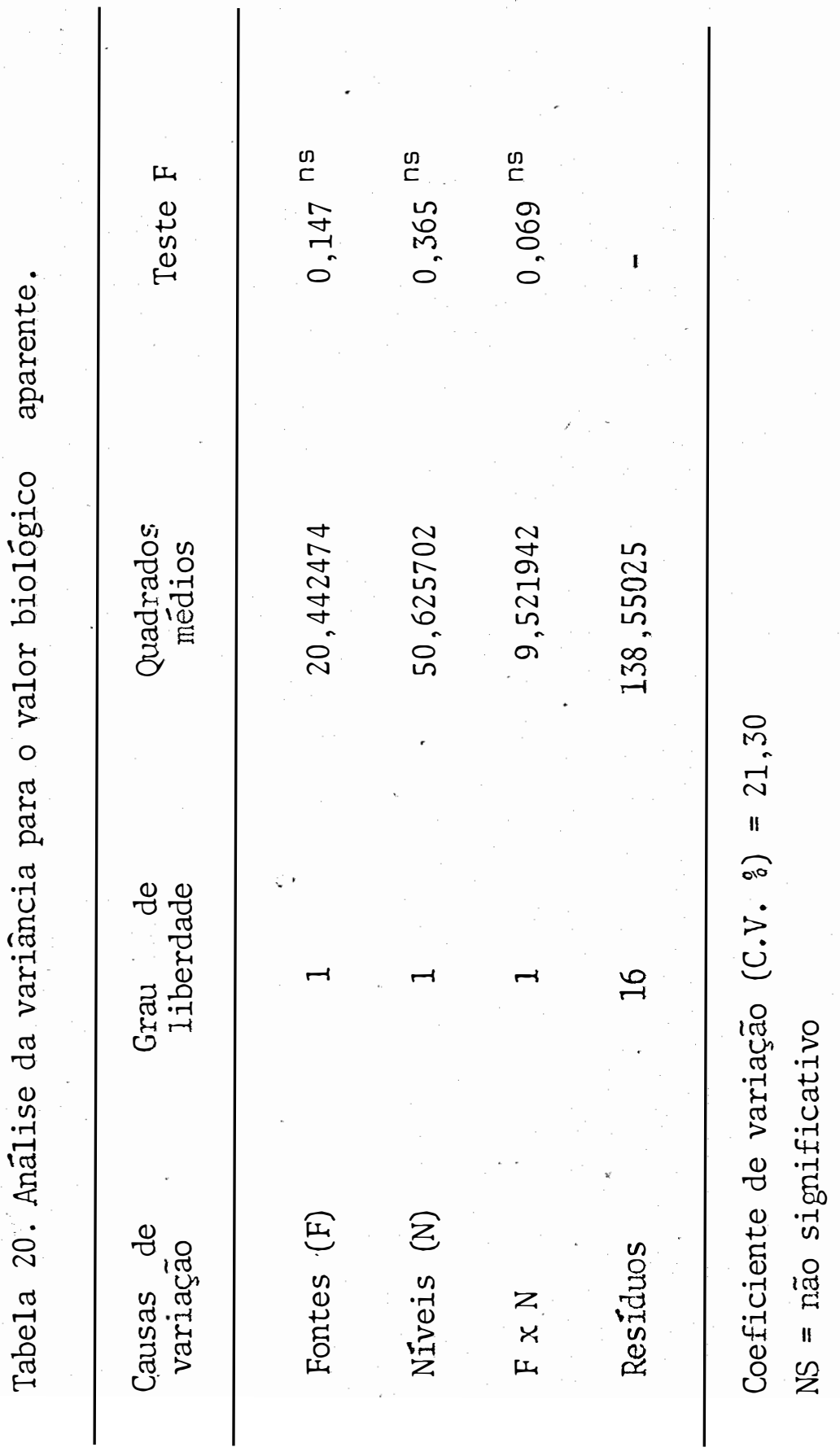


Tabela 21. Médias do nitrogênio retido em relação ao ingerido

\begin{tabular}{|c|c|c|c|}
\hline & \multicolumn{2}{|c|}{ Niveis $\left(\frac{\%}{0}\right)$} & \multirow[b]{2}{*}{ média/fontes } \\
\hline & 8 & 12 & \\
\hline Farelo de scja & 53,33 & 47,87 & 50,60 \\
\hline Levedura seca & 49,39 & 47,01 & 48,20 \\
\hline Mêdia/níveis & 51,36 & 47,44 & 49,40 \\
\hline
\end{tabular}

Tabela 22. Análise da variância para o nitrogênio retido em relação ao ingerido.

\begin{tabular}{lccc}
$\begin{array}{c}\text { Causas de } \\
\text { variação }\end{array}$ & $\begin{array}{c}\text { Grau, de } \\
\text { 1iberdade }\end{array}$ & $\begin{array}{c}\text { Quadrados } \\
\text { médios }\end{array}$ & Teste F \\
\hline Fontes (F) & 1 & 18,70 & $0,20^{\mathrm{ns}}$ \\
Níveis (N) & 1 & 53,27 & $0,58^{\mathrm{ns}}$ \\
F x N & 1 & 15,53 & $0,17^{\mathrm{ns}}$ \\
Resíduo & 16 & 91,29 & - \\
\hline
\end{tabular}

Coeficiente de variação (C.V. : $)=19,47$

NS = não significativo 
.46 .

Tabela 23. Médias do nitrogênio retido em relação ao digerido

\begin{tabular}{|c|c|c|c|}
\hline & \multicolumn{2}{|c|}{ Níveis $\left(\begin{array}{l}0 \\
0\end{array}\right)$} & \multirow[b]{2}{*}{ média/fontes } \\
\hline & 8 & 12 & \\
\hline Farelo de soja & 57,14 & 52,32 & 54,73 \\
\hline Levedura seca & 57,60 & 53,55 & 55,57 \\
\hline mëdia/níveis & 57,37 & 52,93 & 55,15 \\
\hline
\end{tabular}

Tabela 24. Anälise da variância para o nitrogênio retido em relação ao digerido.

\begin{tabular}{lccc}
$\begin{array}{c}\text { Causas de } \\
\text { variação }\end{array}$ & $\begin{array}{c}\text { Grau de } \\
\text { 1iberdade }\end{array}$ & $\begin{array}{c}\text { Quadrados } \\
\text { médios }\end{array}$ & Teste F \\
\hline Fontes (F) & 1 & 8,53 & $0,07^{\mathrm{ns}}$ \\
Níveis (N) & 1 & 67,42 & $0,53^{\mathrm{ns}}$ \\
F x N & 1 & 2,20 & $0,02^{\mathrm{ns}}$ \\
Resíduo & 16 & 126,81 & \\
\hline
\end{tabular}

Coeficiente de variação (C.V. $\stackrel{\circ}{0})=20,50$

NS = não significativo 
.47.

Apesar da inexistência de dados relativos ao valor biológico da levedura seca de Saccharomyces spp.na literatura, pode-se observar que os dados obtidos no presente ensaio estão de acordo com os encontrados para outras espécies de leveduras como mostra SMITH $\S$ PALMER (1976) e SALES et alii (1977).

Os níveis de proteína e a formulação das rações mostraram-se adequados para o tipo de ensaio realizado, pois o balanço de nitrogênio foi positivo, como também não foram observadas anormalidades quanto aos animais, em funçãodos tratamentos a que foram submetidos. Apesar de reduzido, observou-se ganho de peso entre os animais.

Com a finalidade de uniformização, talvez o nível protéico da ração para a determinação do valor biológico da proteína em coelhos pudesse ser fixado em 10,0\%, a exemp1o, do utilizado em ensaios com ratos. 
.48 .

\section{CONCLUSÕES}

Os resultados obtidos permitem concluir que apesar dos coeficientes de digestibilidade aparente da proteína da levedura serem estatisticamente inferiores aos observa dos para o farelo de soja, podem ser considerados altamente fạ voráveis, tendo-se em vista o maior conteúdo de nitrogênio não protéico da levedura.

O menor consumo da ração contendo levedura e 12\% de proteína bruta pode ter contribuído para redução da diferença entre as fontes protéicas estudadas, mas a maior utilização do nitrogênio não protéico da levedura, também pode ser considerado como causa da referida redução.

Com relação ao valor biológico, às diferenças

observadas não foram estatísticamente diferentes e considerando-se a menor concentração de alguns aminoảciodos essenciais 
na proteína da levedura, é perfeitamente lícito admitir que o nitrogênio não protéico contido neste subproduto, foi largamente utilizado pelos microorganismos do ceco para síntese pro téica.

os niveis de proteína das rações mostraram- se adequados para o tipo de ensaio realizado, pois durante todo o período observou-se balanço positivo de nitrogênio e ausên cia de anormalidades quanto aos animais. 


\section{LITERATURA CITADA}

ADAMSON, I e H. FISHER, 1973. Amino acid requeriment of the growing rabbits: an estimative of quantitative needs. The Journal of Nutrition. 'Bethesda, 103: 1306-110.

ADAMSON, I e F. FISHER, 1976. Further studies on the arginine requeriments of the rabbits. J.Nutr. 106: 717-723

A.O.A.C., 1980. Official Methods of Analysis. 11ạ ed. Association of Official Agricultural Chemists, Washington, D.C. $1015 \mathrm{p}$.

ASPLUND, J.M. e W.H. PFANDER, 1972. Production of single-cell protein from solid wastes. In : Alternative Sources of Protein for Animal Production. National Academy of Science Washington D.C. 130-145. 
- ATABEKYAN, G.A., Z.L. AVARKYAN e T.G. ASLANYAN, 1977. Fungus mycellium as a complete protein feed for young rabbits. Nutr. Abs. Revs., 2 (1) : 133.

BALDISSERA, C.N. (1982). Protein metabolism in rabbits. II Congresso Latino-Americano de Cunicultura - Cidade Universitária São Paulo 134p.

BATTAGLINI, M.B. 1968: Importanza della coprofagia nel coniglio domestico, in rapporto alla utilizzazioni di alcuni principi nutritivi. Riv. Zootecn., $6: 21$.

BATTISTI, J.A.; J.A.A. PEREIRA; P.M.A.COSTA; H.S. ROSTAGNO; M.A. Silva e H.V. MEllo, 1985. Composição química e valores energéticos de alguns alimentos para suínos com diferentes idades. Revista da S.B.Z., Viçosa, 14 (2) : 141-150.

- CANTONi, C. e S. D'AUBERT, 1977. Live yeast and their use in animal feeding. Modifications in the intestinal bacteria in rabbits giving pelleted feeds containing live yeast. Nutr. Abs. Revs. Series B, 47 (11): 782.

CARREGAL, R.D., 1976. Efeito da idade e de diferentes níveis de fibra bruta sobre a digestibilidade de nutrientes de rações para coelhos em crescimento. Piracicaba, ESALQ/USP. 70p. (Dissertação de Mestrado). 
COLIN, M. 1975. Effets sur 1a croissance du lapin la supplémentation en L-lysine et en DL-méthionine de régimes végétaux simplifiês. Annales de Zootechnie. Paris, 24: $465-473$

COZZOLINO, S.M.F., 1982. Valor nutricional da Biomassa de Saccharomyces cerevisiae. Estudos em gerações sucessivas de Ratos. São Paulo, Faculdade de Ciências Farmacêuticas/USP (Tese de Doutoramento). $147 \mathrm{p}$.

CHEEKE, P.R., 1971. Arginine, lysine and methionine of the growing rabbits. Nutrition Reports International_ New York 3: $122-128$

DABBAH, R., 1970. Protein from microorganisms, Food Technol. Chicago, 24:659-666.

DESMONTS, R., 1968. Utilização do levedo na alimentação da criança. Pediatria Prâtica São Paulo. 39: 7-18

DURATEX (1985). Comunicação pessoal

FIALHO, E.T.; P.C. GOMES; L.F.T. ALBINO e V. COSTA, 1983. Determinação dos valores de composição química e de digestibilidade de alguns ingredientes nacionais para suínos. Rev. Soc. Bras. Zootec. Viçosa, 12(2): 337-356. 
FIALHO, E.T.; L.F.T. AlbiNO e E. BLUME, 1985. Composição química e valores energéticos de alguns alimentos para suínos. Pesquisa Agropecuâria Brasileira. Brasilia, 20(12) : 1419-1431

GAMAN, E., e H. FISHER, 1970. The essentiality of arginine lysine and methionine for the growing rabbit. Nutr. Rep. Int. $1: 57-64$

HANSEN, J. $\dot{T} \cdot 1981$. Bioproteins in the feeding of growing finishing pigs in Norway. I. Chemical composition, nutrient digestibility and protein quality of pruteen, tropina and methanol based yeast product (Pichia aganobii). J.Animal Phisiol. Anim. Nutr. Verlag, 46 : $: 182-196$.

HUANG, T.C., H.E. UlRICH e C. M. McCAY, 1954. Antibiotics, growt: food utilization and the use of cromic oxide in studies with rabbits, J. Nutrition, 54 : 621 .

HSU, W.C., 1961. Protein from sugar on Taiwan. Sugar y Azúcar. New York, 56 (7) : $33-36$

JACQUOT, R., 1943. Valor nutritivo das leveduras. Sua utilização prâtica para a alimentação humana. In : PAIVA, B.C., Ed., 1966 Boletim Informativo da A,P.M. Piracicaba, $\underline{8}$ (1) ': 1-13, 1966. 
KIHLBERG, R., 1972. The microbe as a source of food. Annual Reviews of Microbiology. California, 26:428-466.

KULWICH, R.L. Struglia e P.B. Pearson 1953. The effect of coprofagy on the excretion of B-vitamins by the rabbit J. Nutrition, 49 : 639

KULWICH, R., P.B. PEARSON, A.H., LANKENAU (1954). Effect of coprofagy upon ${ }^{35} \mathrm{~S}$ Uptake by Rabbits after ingestion of labelled sodium sulfate. Arch Biochem. 드, 180-187

KRIDER, J.L.; J.H. CONRAD; W.W. CARROLL; 1982: Swine Production. 5 ed. New York, McGraw-Hil1 Book Company, 679 p.

LANG, J., 1981. The nutrition of commercial rabbit. Part I Phisiology, digestibility and nutrient requirements. Nutr. Abs e Reviews. Series B, 51 (4)

LEVINE, L. 1977. Biologia do Gene, Editora Edgard BlUcher LTDA São Paulo, 405 p.

LIMA, O.G., 1966. Desenvolvimento da indústria da levedura alimentar e a contribuição brasileira. Brasil Açucareiro. Rio de Janeiro, 67 (3) : 24-25. 
LIMA, G.J.M.M., 1983. Uso da levedura seca (Saccharomyces. cerevisiae) le destilarias de álcool de cana-de-açúcar na alimentação de matrizes suínas em gestação e lactação. Piracicaba. ESALQ/USP. 139p. (Dissert. de Mestrado).

LIMA, U.A.; E. AQUARONE e W. BORZANI, 1975. Tecnologia das fermentações. São Paulo. Edgard Blucher, vol. I, 285p.

MACHADO, P.F. 1983. Valor nutritivo da levedura, resíduo da produção do álcool, para vacas em lactação. Piracicaba, ESALQ/USP. 110p. (Dissert. de Mestrado).

MATTOS, W.R.S.; R.D.D'ARCE; P.F. MACHADO e A.C.M. MARCOS, 1983 Avaliação da qualidade da proteína de levedura seca

(Saccharomyces spp.). Anais da XX Reunião Anual da SBZ. Pelotas $119 \mathrm{p}$.

MAYNARD, L.A.; LOOSLI, J.K; HINTZ, H.F.; WARNER, R.G.; 1979. Animal Nutrition. Seventh Edition. McGraw-Hill Book Company $602 \mathrm{p}$.

MIYADA, V.S. e A. LAVORENTI, 1979. Uso da levedura seca

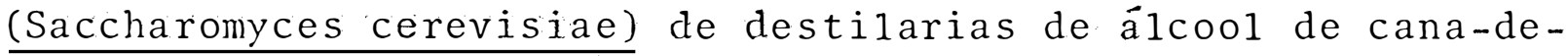
açucar na alimentação de suínos em crescimento e acabamento. Rev. Soc. Bras. Zootecn. Viçosa, 8 (3) : 497-515 
McWARD, G.W., L.B. Nicholson, e B.R. Poulton, 1967. Arginine requeriment of the young rabbit. J. Nutr. 9.2 : 118-120.

NELSON, G.E.N.; R.F. ANDERSON; R.A. RHODES; M.C. SHEKLETON e H.H. HALL, 1959. Lysine, metionine, e trhyptofan content of microorganisms. Applied Microbiology. Baltimore, $\underline{8}: 179-182$

N.R.C., 1977. Nutrient requeriments of Rabbits. National Academy of Sciences. Washington, D.C. $30 \mathrm{p}$.

OLCESE, O., P.B. Pearson e B.S. SCHWEIGERT, 1948. The synthesis of certain B vitamins by the rabbits. J. Nutrition, 35 : 577

OLCESE, O., P.B. PEARSON e P. SPARKS. 1949. Intestinal synthes is of niacin and the metabolic interrelationship of tryptophan and niacin in the rabbit. J. Nutrition, $39: 93$

PEPPLER, H.J., 1970. Food yeast. In : A.H. ROSE e J.S. HARRISON (ed), The yeasts, 2 ed, , London, Academic Press, vol $\underline{3}, 590 \mathrm{p}$.

PIMENTEL GOMES, F., 1985. Curso de Estatística Experimental 11a ed. Piracicaba. Escola Superior de Agricultura"Luiz de Queiroz". $384 \mathrm{p}$. 
PROENÇA, C.E,M., A.S.A.M.T. MOURA, R. POLASTRE e L.E. PEZZATO, 1982. Efeito da levedura de álcool na ração sobre o desempenho ponderal de coelhos In : Anais da XrX Reunião Anual da S.B.Z. Piracicaba, $249 \mathrm{p}$.

ROSE, A.H. e J.S. HARRISON, 1970. The yeasts, vol. 3. Academic Press, London.

SALES, A.M.; T.J.B. MENEZES; M. OKADA; T. ARAKAKI e P.R. LAMO, 1977. Produção e Avaliação nutricional de biomassa proteica de levedura em melaço. Coletânea do Instituto de Tecnologia de Alimentos. Campinas, $\underline{8}: 443-455$

SALGADO, J.M. 1976. Alguns fatores que afetam a qualidade do concentrado protéico obtido em destilarias de álcool. Piracicaba, ESALQ/USP. 50p. (Dissertação de Mestrado)

SCHLOLAUT, W., 1982. The nutrition of the rabbit. ROCHE INFORMATION Service. Animal Nutrition Departament. $60 \mathrm{p}$.

SLADE, L.M.\& ROBINSON, O.W. (1970). Nitrogen metabolism in nonruminant herbivores. II Comparative aspects of protein digestion. J.Animal Sci.; 30, 761-763. 
SLAGLE, S.P. e D.R. ZIMMERMAN, 1979. Evaluation of yeast single cell protein with young pigs. J.Anim. Sci. Albany 49 (5) : $1252-1260$.

SMITH, R.H. e R. PALMER, 1976. A chemical and nutritional evaluation of yeast and bacteria as dietary protein sources for rats and pigs. J. Sci. Fd. Agric., Osford, 27: 76.3-770

SPREADBURY, D., 1978. A study of the protein and aminoacid requeriments of the growing New Zealand white rabbit with emphasis on lysine and the sulphur-containing aminoacids. British Journal. Nutrition, $39: 601-613$

STANIER, R.Y.; M. DOUDOROFF e E.A. ADELBERG, 1969. O mundo dos. micróbios. São Paulo, Editôra Edgard Blucher Ltda. 741 p.

TAYLOR. E.L., 1940. The demonstration of a peculiar kind of coprophagy normally practised by the rabbits. Vet. Rec., $\underline{52}$ 259 .

THACKER, E.J. e C.S. BRANDT, 1955. Conrofagy in the rabbits J. Nutrition, 55: 375-385. 
VANANUVAT, P., 197\%. Value of yeast for poulty feeds Critical Reviews in Food Science and Nutrition. Ames, 9 (4) : 325-343.

YOUSRI, R.F. 1982. Single cell protein: its potential use for animal and human nutrition. World Rev. Anim. Prod. Roma, 18 (2) : 49-67. 
.60.

\section{APENDICE}




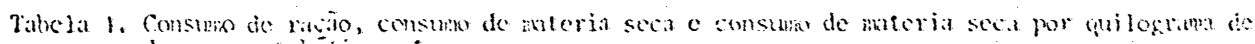
de peno metantice.

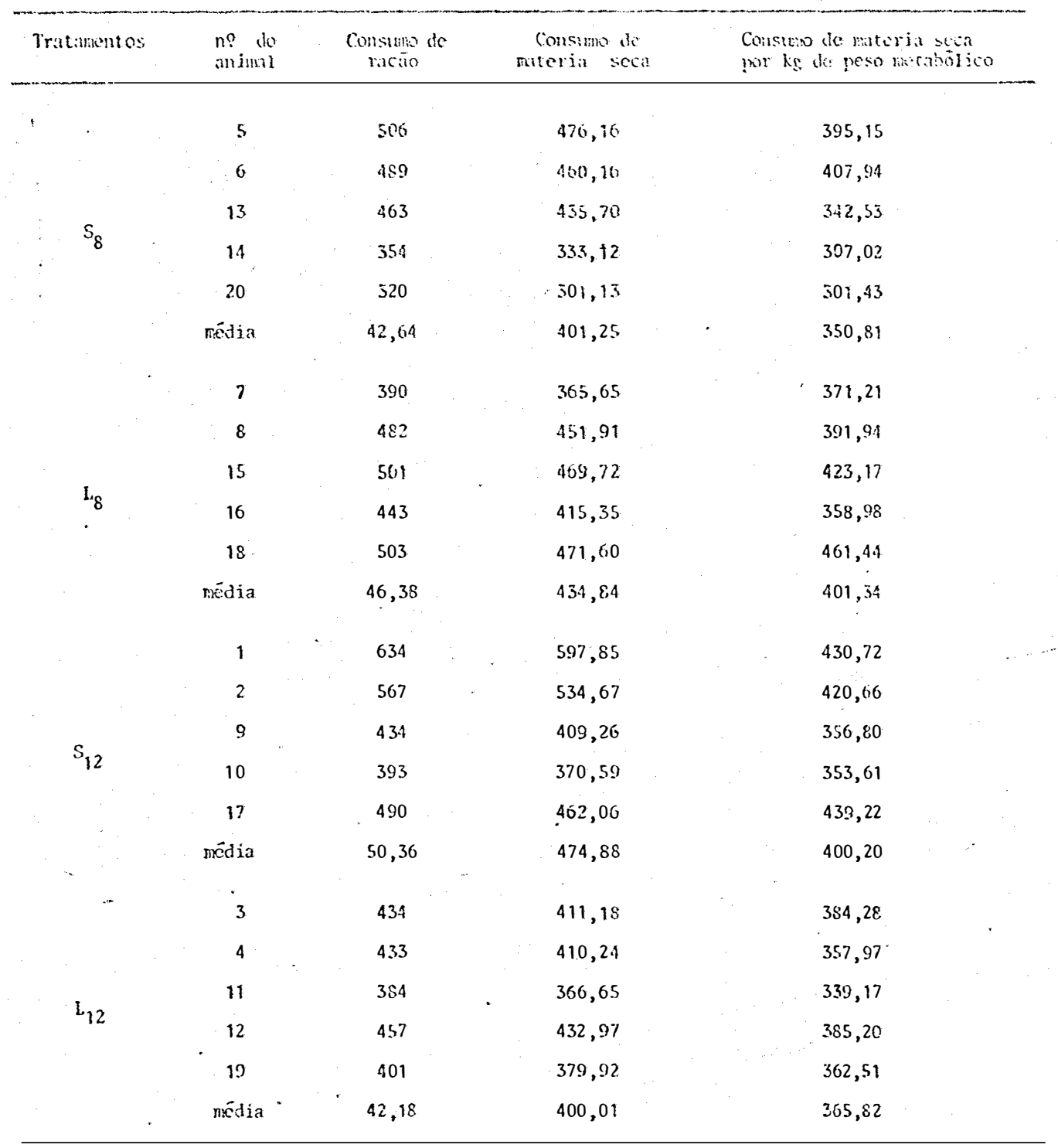


Taled a 2. Ingestio e corcino de nitrogenio (on grams) dume o periodo de coleta.

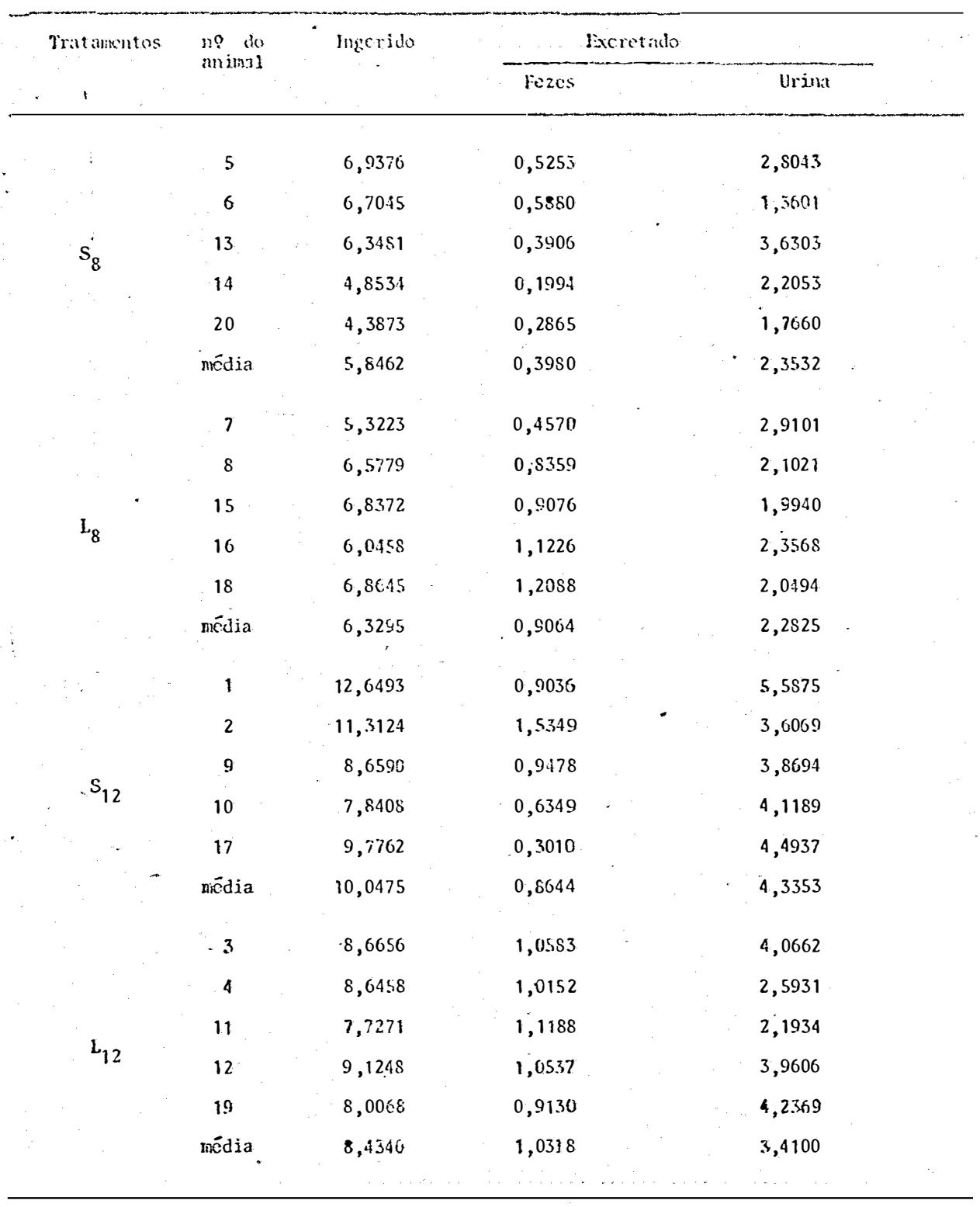




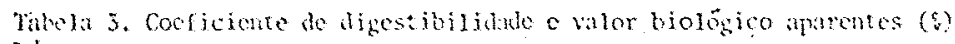

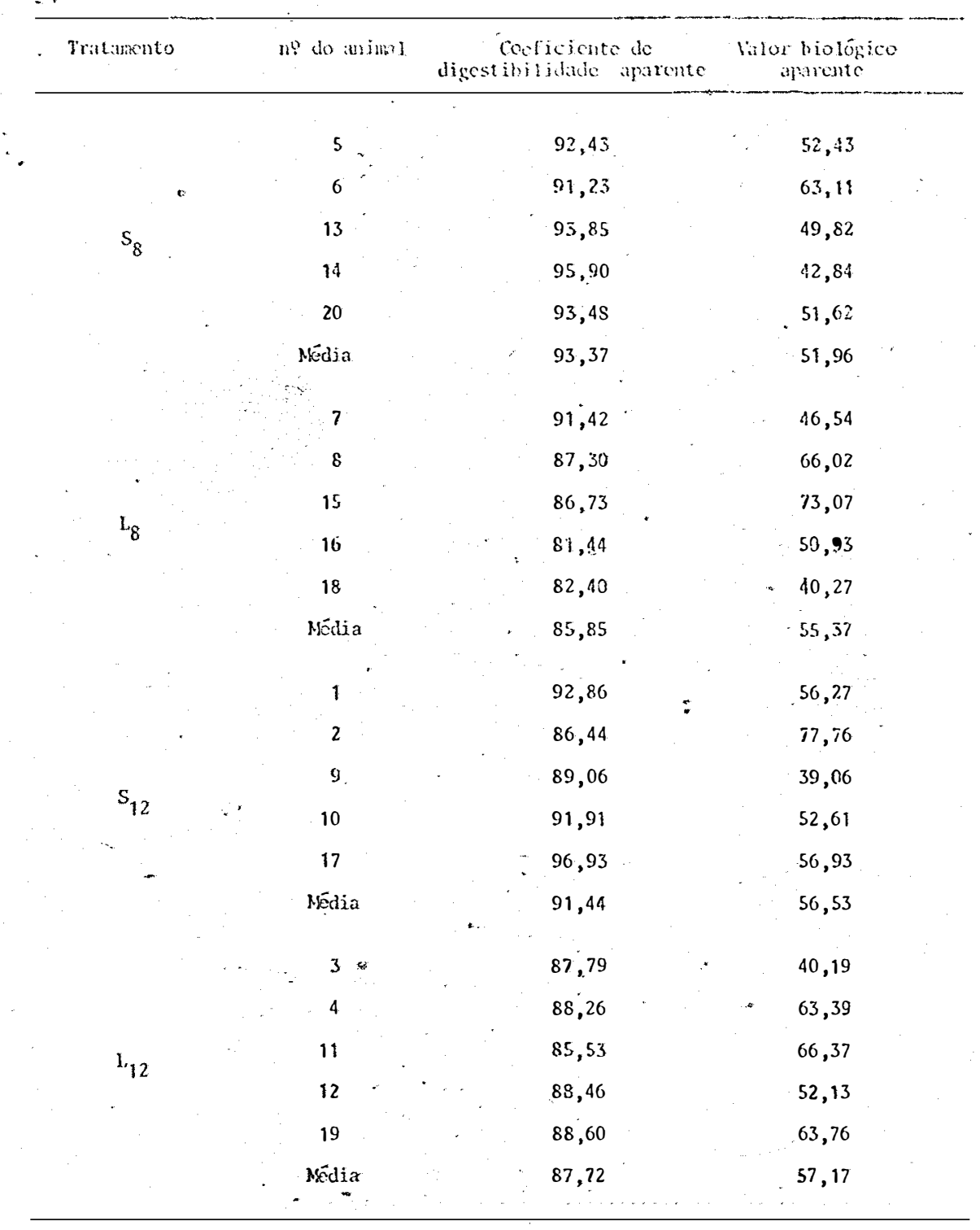


Tahela 4. Retensio de nitrogenio ent relajo no nitrogên ingerido e digerido

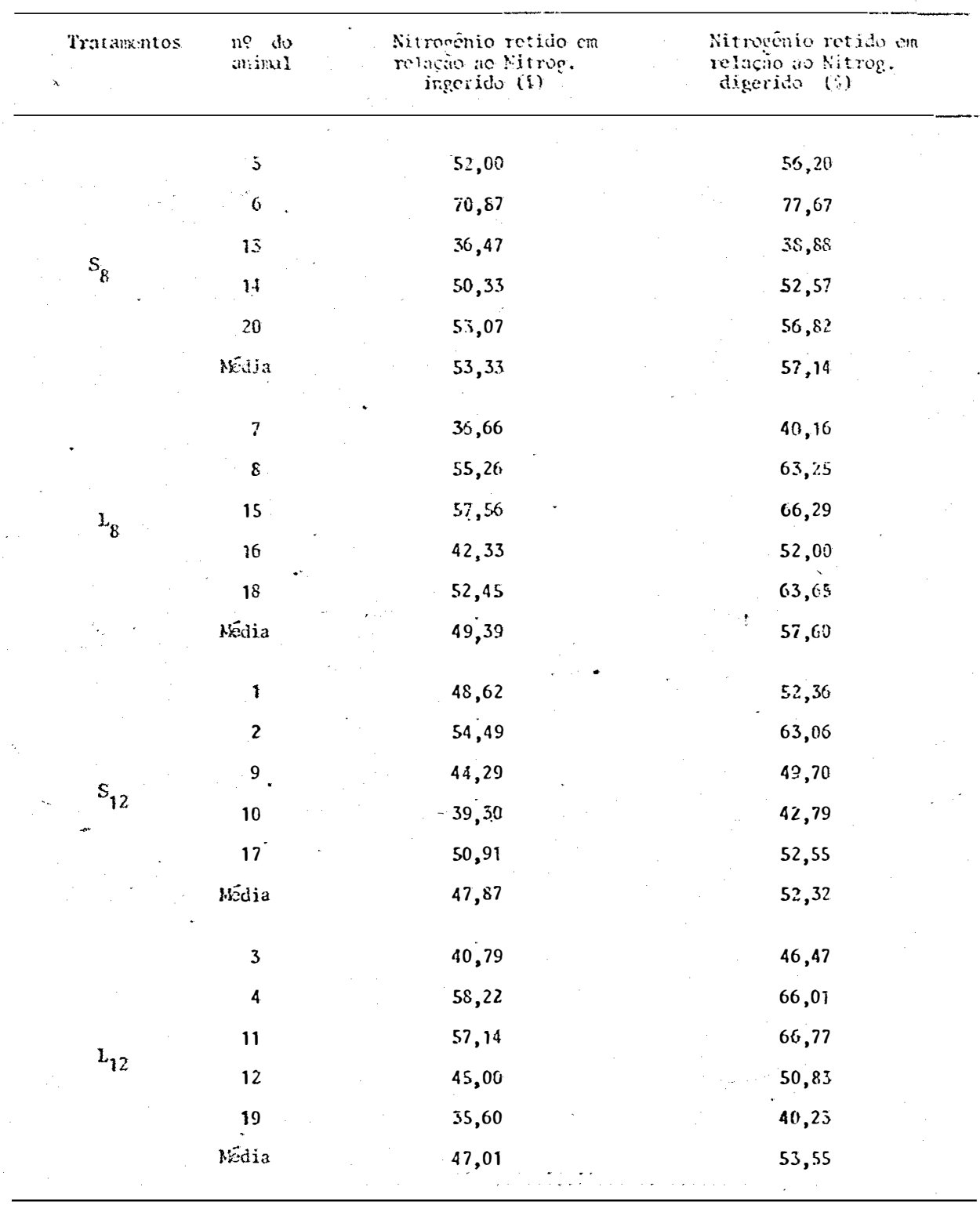

